Historic, archived document

Do not assume content reflects current scientific knowledge, policies, or practices. 

10 Per Cient Discount

On all plants bought from this catalogue and paid for in full before August 1, 1932, we will allow 10 per cent discount.

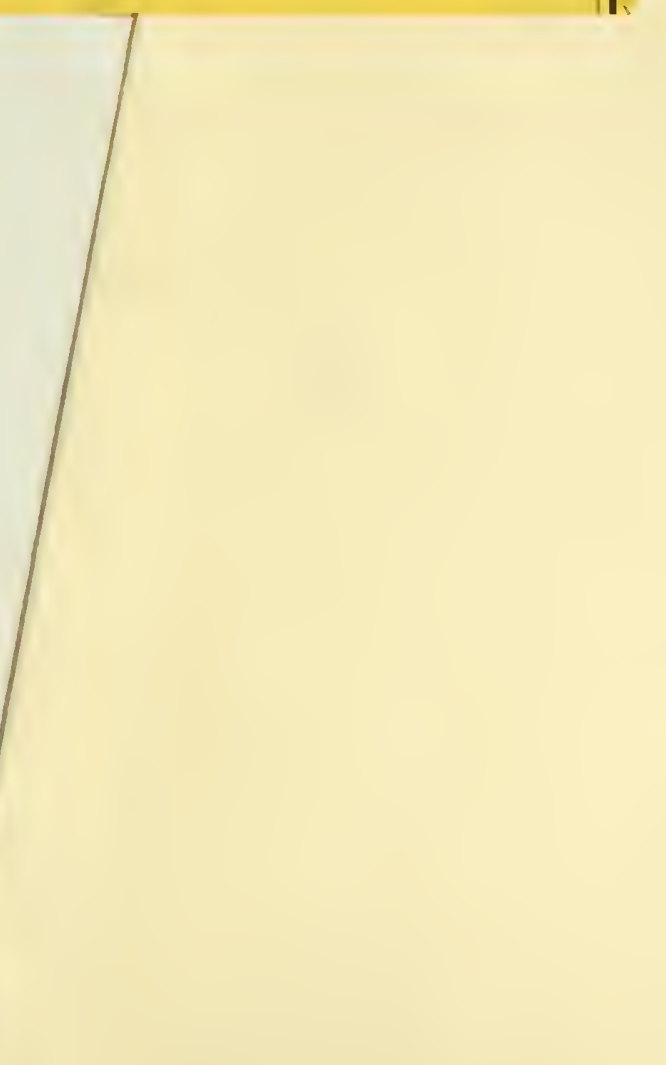





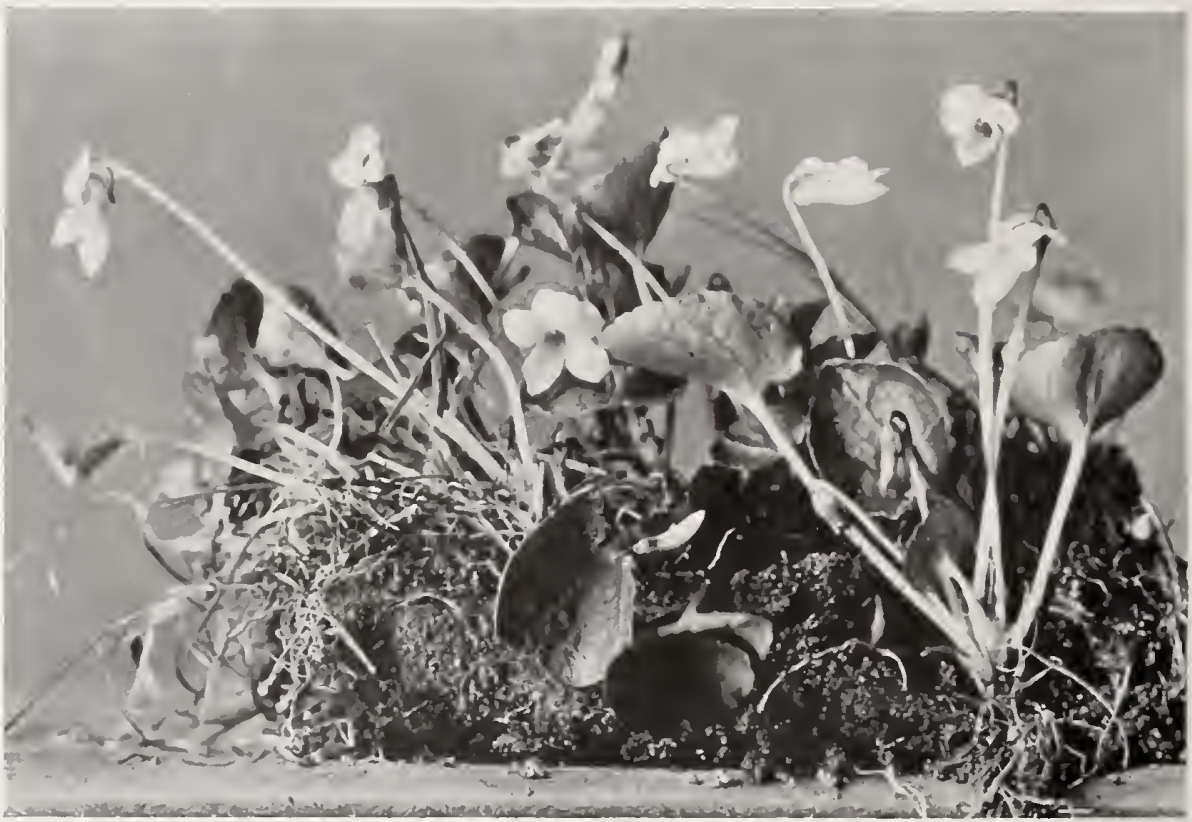

VIOLA BLANDA (Sweet White Violet) (See page 19)

\section{North American Wild Flowers}

O

u fourth catalog of native North American Wild Flowers and Ferns contains many delightful species which we have not listed heretofore. For this season's sales we have easily the best supply we have ever had. We have several thousand fine plants of Trailing Arbutus and Fringed Gentian, as well as all varieties of Ladyslipper native to eastern North America.

The support which has been given our work in growing our native plants has been highly gratifying, and we hope this season to sell more than ever. Without the help of our customers who buy these plants, we should be unable to continue our work in putting the propagating and growing of rare wild flowers on a commercial basis, and unless this is done, many of the finest varieties will become very scarce indeed within a few years.

ABout Prices-As we ship our plants to all the states and many far corners of the earth. we necessarily make all prices f.o.b. Putney, Vermont. Unless instructed otherwise we will send either by mail or express collect, whichever seems best.

TERMS-Fifty or more plants of one variety will be sold at 100 rates; 250 or more of one variety will be sold at 1000 rates.

Time to PL.1NT-In general, most wild flowers transplant best in late August and lieptember, although there are exceptions to this rule.

Visitors-We are always glad to have people interested in the growing of wild llowers visit our nurseries.

Would you like

\section{A BOOK ON GROWING WILD FLOWERS ?}

We are continually getting requests for more complete cultural directions for wild flowers than are given in this small catalog. While we would tike to make our catalog more complete and with more instructions, yet we cannot afford to make it any more entertaining and instructive than it is now. We receive requests for hundreds of copies each year from schools and colleges for classroom work.

If the people who are interested in wild flowers and their culture show sufficient interest in a more complete work, well illustrated and free from advertising. to purchase enough copies to warrant the printing of such a book, we shall be glad to provide it. The price would not be exorbitant. If you are willing to buy" a book of this nature, will you tell me so at once?

\section{GEORGE D. AIKEN, PUTNEY, VERMONT}




\section{GENERAL LIST of North American Wild Flowers}

Prices per 1000

ACONITUM uncinatum (Clambering Monkshood). This is the native climbing Monksliood of the Southern Mountains. Its attractive blue flowers are most noticeable in July. 1t likes rich soil

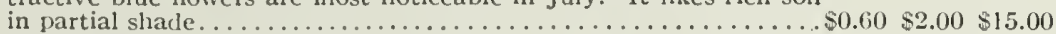

ACORUS calamus (Sweetflag). The source of candied Sweet flag root and desirable for bogs. It grows $2 \mathrm{ft}$. tall $\ldots \ldots \ldots \ldots \ldots \ldots \ldots \ldots$

ACTAEA alba (White Baneberry). Growing in rich hardwoods, the IIhite Baneberry with its fluffy flowerheads and later, the pure white berries on crimson stems is one of our finest native flowers. 1t grows from 2 to $21 / 2 \mathrm{ft}$. tall.

rubra (Red Baneberry). When in bloom, this can hardly be told from the White Bancberry, but the fruit is a dazzling scarlet. It is not

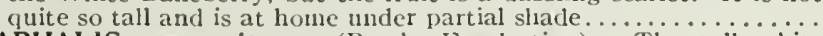

ANAPHALIS margaritacea (Pearly Everlasting). The tall white Everlasting which is known to everyone who spent their childhood on an Eastern farin and which is used to considerable extent in dried bouquets by florists.

ANEMONE canadensis (IIeadow Anemone). This variety continues the loveliness of the IIindflower on a larger scale, attaining a height of 12 to $18 \mathrm{in}$. with flowers an inch or more broad. Nay to August.

cylindrica (Thimbleweed). The tallest growing native Anemone, holding its beautiful, creamy white blossoms over $2 \mathrm{ft}$. from the ground. The seeds are in late Summer in a mass of wool, causing the school children to call this plant "Sheep's Wool." It prefers full stunquefolia (vindflower). This is one of the loveliest of our native quinquefolia (Windflower). This is one of the loveliest of our native
flowers. and is quite casy to grow in moist shade. 1ts pure white

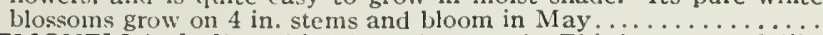

ANEMONELLA thalictroides (Rue Anemone). This is very much like the Windlfower, except that it has several flowers to the stem......

AQUILEGIA canadensis (American Columbine). Our wonderful native Columbine so hardy and so delightful in the rock garden, y.iclding a profusion of red and yellow flowers about Memorial Day. it will grow in either sun or sliade and reaches about a foot in height. caerulea (Colorado Columbine). The state flower of Colorado. It bears immense blue and white blossoms on rather fragile stems....

chrysantha. This bright yellow, long spurred Aquilegia from the Rocky Mountains is very easy to grow and blooms nearly all Summer in sun or partial shade. It grows $2 \mathrm{ft}$. or more in height.....

$\begin{array}{llll}.50 & 1.50 & 8.00 \quad \$ 60.00\end{array}$

$\begin{array}{llll}60 & 2.00 & 15.00 & 125.00\end{array}$

$\begin{array}{llll}60 & 2.00 & 15.00 & 125.00\end{array}$

$\begin{array}{llll}.60 & 1.50 & 12.00 & 100.00\end{array}$

(6) $1.75 \quad 12.00 \quad \ldots \ldots$

$\begin{array}{llll}.60 & 1.75 & 10.00 \quad 80.00\end{array}$

$\begin{array}{llll}.60 & 1.75 & 10.00 & 80.00\end{array}$

$.60 \quad 2.00 \quad 15.00 \quad \ldots \ldots$

$\begin{array}{llll}.60 & 2.00 & 12.00 & 110.00\end{array}$

$\begin{array}{llll}.60 & 2.00 & 15.00 & 140.00\end{array}$

$\begin{array}{llll}.60 & 2.00 & 15.00 & 140.00\end{array}$

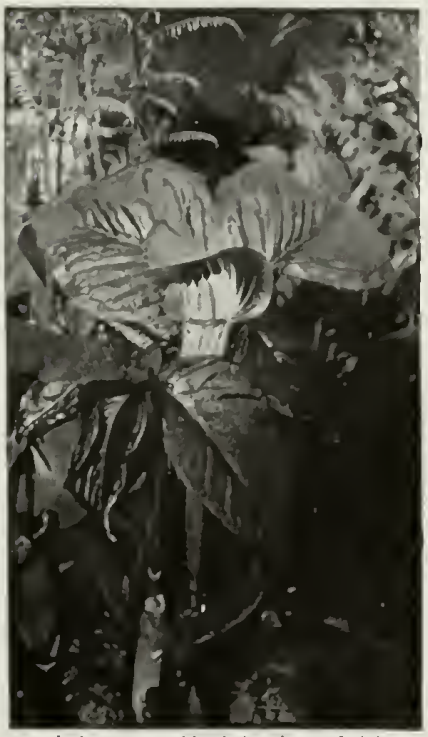

Arisaema (Jack-in-the-pulpit)

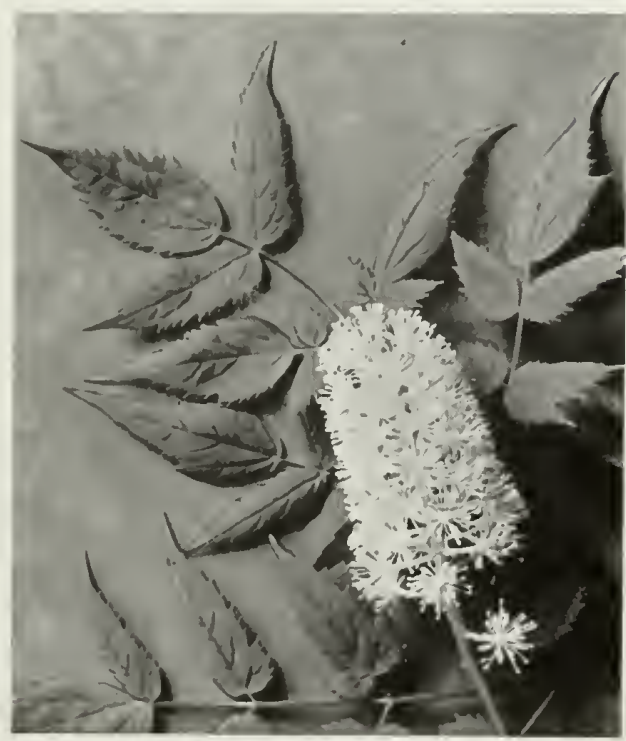

Actaea rubra (Red Baneberry)

This price list is for Fall, 1932 only and does not apply to orders for Spring, 1933 


\section{Prices per}

$3 \quad 12$

100

1000

ARALIA hispida (Bristly Sarsaparilla). This Aralia will grow in full sun. Its greenish yellow flowers are borne in June on 1 to $2 \mathrm{ft}$. plants. It has blue fruit in Autumn
nudicaule (Wild Sarsaparilla). This fellow likes shade and while the yellowish flowers in May are not conspicuous, the large blue berries in late Summer make it a desirable plant. It grows $1 \mathrm{ft}$. tall....... racemosa (Spikenard). This also has a greenish white flower in May, but the berries are red. It grows $2 \mathrm{ft}$. tall in moist shade.........

ARISAEMA dracontium (Green Dragon). Is not as savage as it sounds, but is a peculiar form of Jack in which the spadex is long and tapering like a bayonet

tryphyllum (Jack-in-the-pulpit). Jack is a most agreeable inhabitant of the wild garden making friends with everyone, especially the children. He will grow $12-15$ in. tall in moist shade. We can furnish either the common purple or green variety..............

ASARUM canadense (Gingerroot, Wild Ginger). A plant that is different. It bears curious brown flowers on creeping stalks in April, has beautiful foliage and a ginger flavored root. It prefers

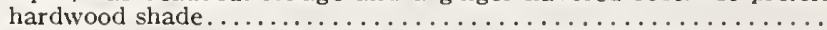

ASCLEPIAS incarnata (Swamp Milkweed). The reddish flowers are borne on 2 to $3 \mathrm{ft}$. stalks in July and are most attractive. It is most at home in bogs.......... . . . . . . . . . . . . . . . . . . . . . . . wild flowers, and the orange flowers growing on the dry, sunny banks in July always attract much attention. It grows to about $2 \mathrm{ft}$. in height.

$0.60 \$ 1.50 \$ 10.00$

$\begin{array}{lll}.60 & 1.50 & 10.00\end{array}$

$\$ 90.00$

$\begin{array}{lll}.60 & 2.00 & 15.00\end{array}$

$.75 \quad 2.50$

$.60 \quad 1.50 \quad 12.00$

$\begin{array}{llll}60 & 1.50 & 10.00 \quad 80.00\end{array}$

$\begin{array}{llll}.60 & 2.00 & 15.00 & 140.00\end{array}$

$.60 \quad 2.00 \quad 15.00 \quad 140.00$

ASTER cordifolius (Heartleaved Aster). A roadside Aster with lilac flowers borne in great masses during September and October. It

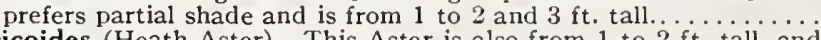

ericoides (Heath Aster). This Aster is also from 1 to $2 \mathrm{ft}$. tall, and bears such a profusion of white, snowflake-like flowers in Autumn as to form imitation snow drifts.

novae-angliae (New England Aster). A tall, magnificent Aster, which splashes the fields and roadsides with varying shades of

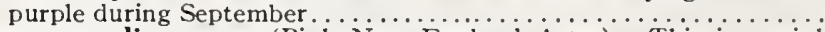

novae-angliae rosea (Pink New England Aster). This is a pink variation of the New England Aster

novibelgi (New York Aster). The wild blue violet Aster from which most of the named varieties of garden Asters have been selected. It prefers the open meadows. . . . . . . . . . . . . . . . . . .

puniceus (Swamp Aster). A very tall, lavender colored Aster for

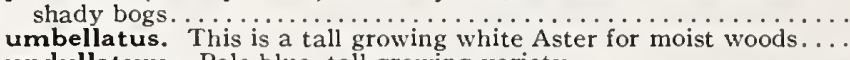

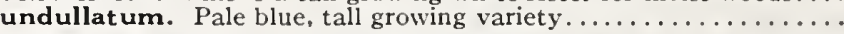

BAPTISIA bracteata (White Wild-indigo). This Baptisia has tall spikes of pure white, and prefers the open dry slope. It attains a

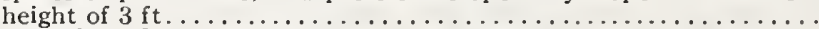

leucantha (Cream Wild-indigo). The earliest of the Baptisias to blossom, bearing drooping spikes of cream white flowers in June.

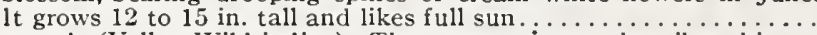

tinctoria (Yellow Wild-indigo). The common name describes this variety of Baptisia. It grows 2-3 ft. high and blossoms in late Summer

CALLA palustris (Wild Calla). The miniature white Callas grow 6 in. tall in shady bogs and are one of the most charming inhabitants of

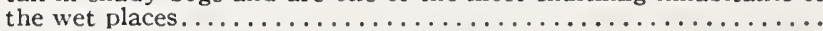

CALLIRHOE involucrata (Poppy Mallow). This is a sprawling plant for dry, sunny slopes, spreading $3 \mathrm{ft}$. across and bearing extremely brilliant flowers of pure magenta, a beautiful color, not the

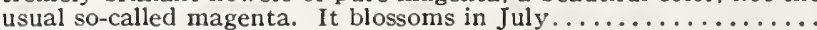

triangulata. An erect growing Poppy Mallow from the Prairie States, attaining a height of $18 \mathrm{in.}$ and bearing its flowers in panicles.

CALOCHORTUS albus (White Globe Tulip). This is a native of the western states. It should be grown in open sun and grows to about 8 in. in height.

amabilis (Yellow Globe Tulip). Another Calochortus which grows to be about $8 \mathrm{in}$. tall. This is one of the easiest to grow and has been very satisfactory with us . . . . . . . . . . . . . . . . . . .

venustus (Mariposa Tulip). Its coloring varies, but is mostly white with varicolored markings. It seems to stand our Winters safely and is a welcome immigrant from the Pacific states.............

CALOPOGON pulchellus. Dainty little Orchid growing in bogs. Of similar color to the Pogonia, but bearing several flowers on a stalk.

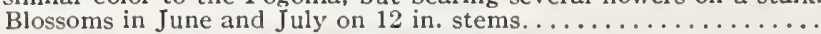

$\begin{array}{llll}.60 & 1.50 & 10.00 & 80.00 \\ .60 & 1.50 & 10.00 & 80.00 \\ & & & \\ .60 & 1.50 & 12.00 & 100.00 \\ .60 & 2.00 & 15.00 & \ldots \ldots \\ & & & \\ .60 & 1.75 & 12.00 & 100.00 \\ .60 & 1.50 & 12.00 & \ldots \ldots \\ .60 & 1.50 & 12.00 & \ldots .00 \\ .60 & 1.50 & 12.00 & 100.00\end{array}$

$\begin{array}{llll}.60 & 2.00 & 15.00 & 120.00\end{array}$

$\begin{array}{llll}60 & 2.00 & 15.00 & 120.00\end{array}$

$.60 \quad 2.00 \quad 15.00 \quad \ldots \ldots$

$\begin{array}{llll}60 & 1.50 & 12.00 & 100.00\end{array}$

$\begin{array}{llll}60 & 2.00 & 15.00 & 130.00\end{array}$

$\begin{array}{llll}60 & 1.75 & 12.00 \quad \ldots \ldots\end{array}$

$\begin{array}{llll}.25 & .75 & 6.00 \quad 55.00\end{array}$

$.25 \quad .75 \quad 6.00 \quad 55.00$

$.40 \quad 1.25 \quad 10.00$

$\begin{array}{lll}75 & 2.50 & 18.00\end{array}$

This price list is for Fall, 1932 only and does not apply to orders for Spring, 1933 


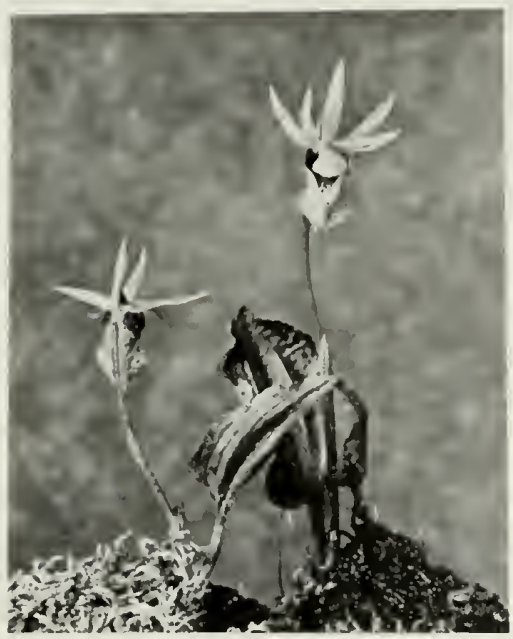

Calypso bulbosa

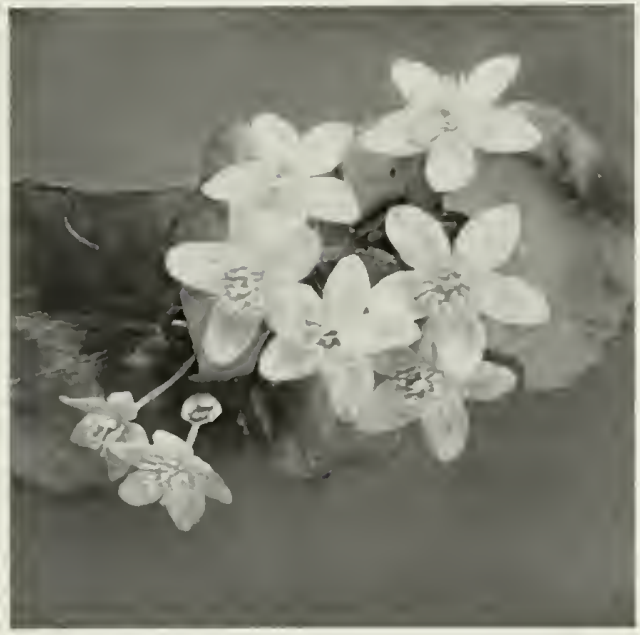

Caltha palustris (Wild Marshmarigold)

CALTHA palustris (Wild Marshmarigold). One of our best native wild flowers, and with its gleaming golden flowers borne in greatest profusion, brightens the meadows and bogs in early Spring.... . . . . \$0.60 \$1.50\$10.00

CAL YPSO bulbosa. A rare little Orchid growing only 2 in. tall, found nrincipally in the Western Mountains, but naturalized to some

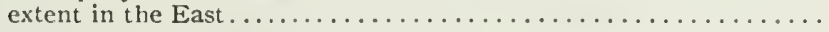

CAMAS:IA esculenta (Wild Hyacinth). The Camassias are excellent for mass planting in moist or semi-shady locations. The bulbs were a favorite food of the Indians. The plants grow to about $2 \mathrm{ft}$. in height and the flowers vary from cream to blue..............

leichtlini. This is a taller growing, rare variety, usually in deep blue. The Camassias blossom in May with us.................

CAMPANULA rotundifolia (Bluebells of Scotland). This plant seems fragile, but when once established in the cracks and ledges or in almost any other situation, it seems to live indefinitely and yields a profusion of delicate blue bells throughout the Summer..........

CASSIA marilandica (Wild Semna). A shrubby perennial from 3 to $5 \mathrm{ft}$. tall, bearing large clusters of yellow, pea-shaped flowers in late Summer, and rather attractive, fernlike foliage. It prefers an open, moist location.

$\begin{array}{lll}.60 & 1.50 & 10.00\end{array}$

$.60 \quad 1.75 \quad 12.00$

$\begin{array}{llll}60 & 2.00 & 15.00 & 135.00\end{array}$

$.60 \quad 2.00 \quad 15.00$

CAULOPHYLLUM thalictroides (Blue Cohosh). The: new shoots of the Blue Cohosh are a royal purple. The flowers are yellow with purple sepals and the fruit in late Summer is purple. It grows $2 \mathrm{k}$.

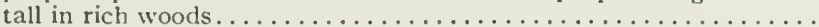

CHELONE glabra (Turtlehead). Although quite common, the Turtlehead is indispensable in bog gardens. Its Snapdragonlike flowers are produced in late Summer on $2 \mathrm{ft}$. stems, in moist shade or sun. .

CHIMAPHILA maculata (Spotted Pipsissewa). Instead of the solid green leaves of the common Pipsissewa, this variety is splotched with white along the midrib, and the flowers are also whiter......

umbellata (Pipsissewa). If this plant were a inore robust grower, it would be the finest ground cover for shade. It grows after the fashion of I achysandra and produces its white flowers in July and August . . . . . . . . . . . . . . . . . . . . . .

CHIOGENES hispidula (Creeping Snowberry). One of the most beattiful little creeping evergreen vines of the North woods. It is perfectly happy when growing over a rotten Hemlock or Spruce log and so in ust have very acid soil in which to thrive. The waxy white ber-

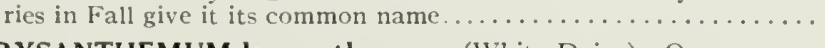

CHRYSANTHEMUM leucanthemum (White Daisy). Our common white Daisy so necessary at graduation time. $\begin{array}{llll}.50 & 1.50 & 8.00 \quad 75.00\end{array}$

This price list is for Fall, 1932 only and does not apply to orders for Spring, 1933 


\section{Prices per 3}

12

100

1000

CICUTA maculata (Waterhemlock). This plant has immense pure white umbels of flowers in June and July. It is a giant among native plants, growing several feet tall in rich moist shade. It is supposed

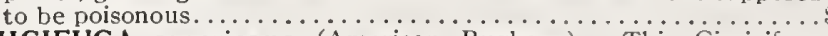

CIMICIFUGA americana (American Bugbane). This Cimicifuga grows more like a large Baneberry than the Black Cohosh. It will grow to a height of 2 to $3 \mathrm{ft}$. in inoist shade.

racemosa (Black Cohosh). The picturesque spikes of this Cimicifuga blossom in August, in moist, partial shade. Its height is from 4 to

CLAYTONIA virginica (Springbeauty). The dainty, pink striped flowers of this plant come in early Spring. It prefers partial shade

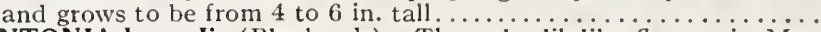

CLINTONIA borealis (Blucbcads). The pale, lilylike flowers in May of this Clintonia, the glossy green, prostrate lcaves and the bright blue berries in late Summer make this a welcome inhabitant of the

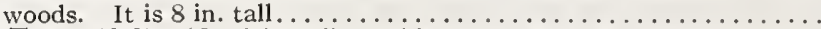

COPTIS trifolia (Goldthread). This plant gets its name from the golden threadlike roots. The leaves are almost evergreen and the

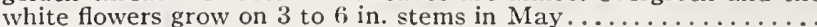

CORNUS canadensis (Bunchberry). Bunchberry is an excellent ground cover for acid soil. The flowers resemble those of the Cornus floridus and the fruit is a bright red. Its leaves are semi-evergreen.

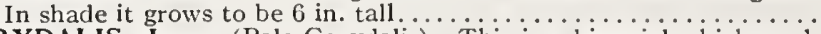

CORYDALIS gIauca (Pale Corydalis). This is a biennial which seeds itself freely. Its open pink, heartshaped flowers blossom in May and

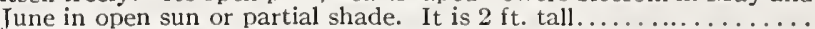

CYPRIPEDIUM acaule (Pink Moccasin Flower). The pink Moccasin Flower supplies color for the pine woods of New England. This largest flowered Ladyslipper will grow also in hardwood shade and sometimes in open sun, if the soil is acid. It blossoms in May.....

acaule alba (White Moccasin Flower). We have a few hundred plants of the snow white Cypripedium acaule. One of the rarest Ladyslippers, which requires similar treatment to its pink relative.

arietinum (Ramshead Ladyslipper). A beautiful, small, rare Ladyslipper, colored red and white, with prominent veins, blooming

californicum. ¿ far Western Ladysiper which has survived two Winters in Vermont successfully. Small blossoms of white with

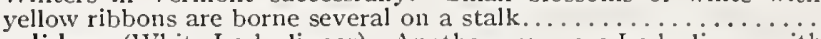

candidum (White Ladyslipper). Another very rare Ladyslipper with purest white flowers on $1 \mathrm{ft}$. stems. It takes readily to cultivation if the soil is sweet.

montanum. A fine, pure white Ladyslipper from the Western Mountains. It seems to grow readily here in Vermont in strong, slightly acid soil.

pubescens (Yellow Ladyslipper). The Yellow Ladyslipper is the most easily domesticated of the Ladyslippers. It is grown in full sun or

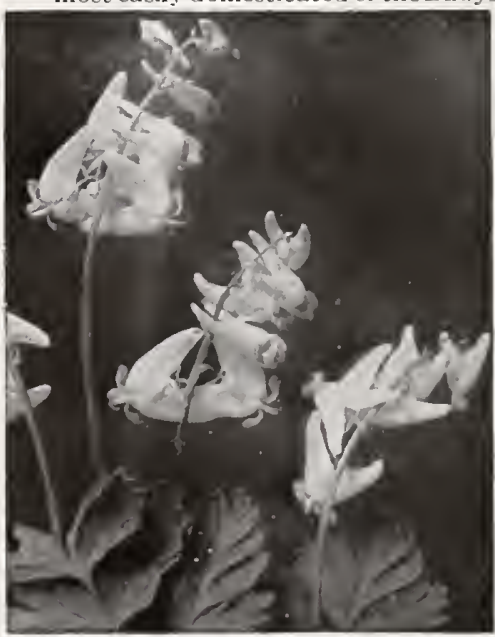

Dicontra cucullaria (Dutchmans-breeches (See page 7) shade, and is very fragrant. Its clear y'ellow flowers have brown or green sepals. The dividing line between parviflorum and pubescens is so faint that we are offering but the above named variety...

$60 \quad 2.00 \$ 15.00 \$ 120.00$

$\begin{array}{llll}.60 & 2.00 & 15.00 & 120.00\end{array}$

$\begin{array}{llll}.50 & 1.00 & 8.00 & 60.00\end{array}$

$\begin{array}{llll}.50 & 1.50 & 10.00 & 80.00\end{array}$

$\begin{array}{llll}.50 & 1.50 & 8.00 & 60.00\end{array}$

$\begin{array}{llll}.60 & 2.00 & 15.00 & 135.00\end{array}$

$\begin{array}{llll}.60 & 2.00 \quad 15.00 \quad \ldots \ldots\end{array}$

$\begin{array}{llll}.60 & 2.00 & 15.00 & 135.00\end{array}$

3.0010 .00

3.0010 .00

$1.50 \quad 5.00$

$3.00 \quad 10.00$

$1.50 \quad 5.00$

spectabile (Showy Ladyslipper). The spectabile is considered the most desirable of our native orchids of the north. It will grow in moist shade, about $2 \mathrm{ft}$. tall and blossons freely in Jine

$\begin{array}{llll}1.15 & 4.00 \quad 30.00 \quad 275.00\end{array}$

DALIBARDA repens. splendid little plant of the rich hardwoods. The leaves are crergreen and the white Hepaticalike blossoms are borne on 2.3 in. stems.............

$\begin{array}{llll}.75 & 2.00 & 15.00 & 135.00\end{array}$ 


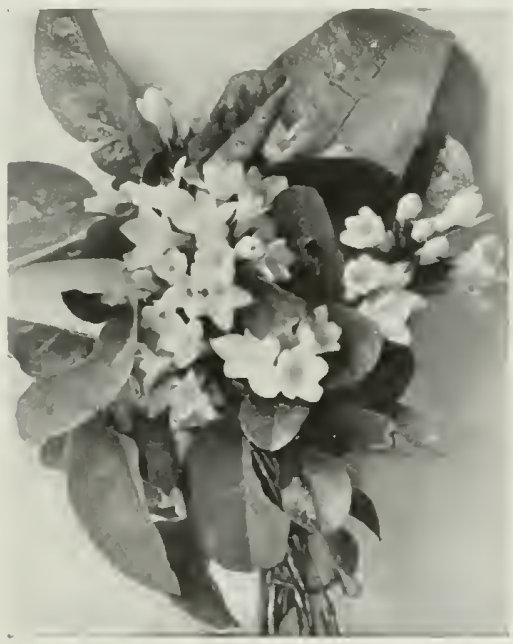

Epigaea repens (Trailing-arbutus)

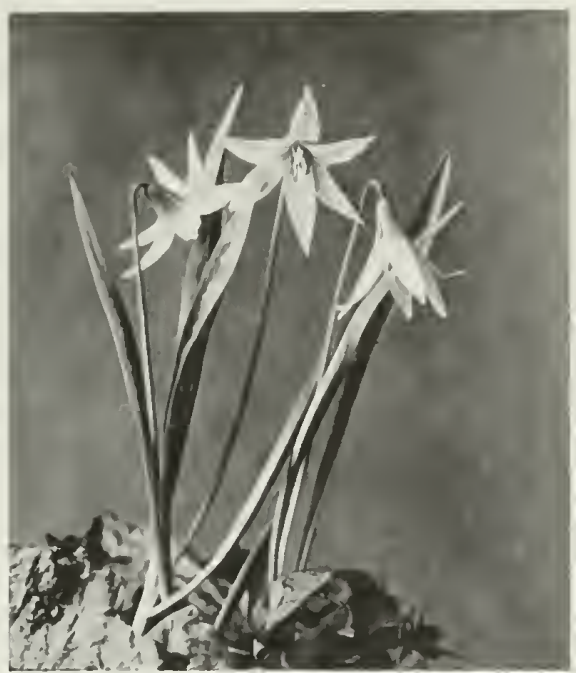

Erythronium albidum (White Troutlily) (See page 8)

Prices per

3

12100

1000

DELPHINIUM tricorne (Rock Larkspur). A delightful little dark blue wild Delphinium from the central states. $1 \mathrm{ft}$. tall and blossoms before any of the cultivated Delphiniums. It is very attractive and the plants seem long lived when planted in the open sun and given

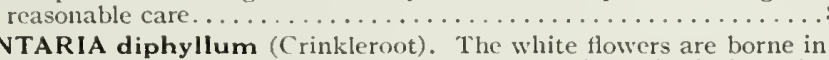
clusters in early spring. The plant attains a height of $1 \mathrm{ft}$. in moist

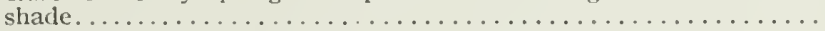

DIANTHUS deltoides (Maiden Pink). The foliage of this Maiden Pink is grasslike and the blossoins are borne profusely in June..........

DICENTRA canadensis (Squirrelcorn). This is a splendid rock plant with dainty, fernlike foliage. The flowers are white and heartsliaped with pink edges.

cucullaria (Dutchmans-breeches). This Dicentra has leaves and blossoms like the Squirrelcorn except that the blossoms are edged

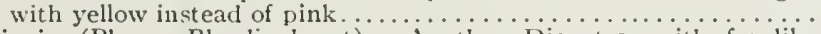

eximia (Plumy Bleedingheart). Another Dicentra, with fernlike foliage and pink flowers, which blossoms throughout the Summer. 1t grows about $1 \mathrm{ft}$, tall in moist, partial shade..............

DIONAEA muscipula (Venus Flytrap). A queer little plant with tastes similar to the Pitcherplant, for when insects alight on the flat, hairy leaves, they close up on the prisoner and the plant digests him at its

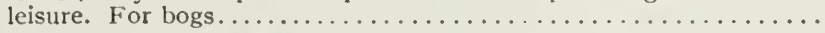

DODECATHEON meadia (Shootingstar). This is a delightful contribution from the Central West. The blossoms vary from white to purple. Shootingstar likes the full sun or the open woods........

DROSERA rotundifolia (Round-leaved Sundew). White flowers are borne on 4 to 5 in. stems, but the curious hairy leaves are what make this plant desirable for the moist, open land...............

ECHINACEA angustifolia (Narrowleaf Coneflower). A low growing Coneflower less than $1 \mathrm{ft}$. tall. From the limestone cliffs and slopes

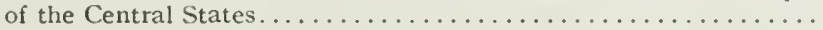

purpurea (Purple Coneflower). A pink, Daisylike flower from the

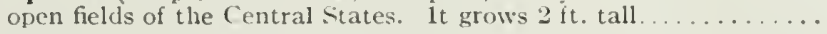

EPIGAEA repens (Trailing-arbutus). Tlis is the well known Mayflower. It must have acid soil and likes partial shade. The plants

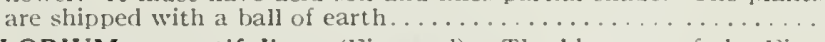

EPILOBIUM angustifolium (Fireweed). The blossoms of the lireweed are brilliant masses of inagenta on the hillsides in July.

angustifolium alba (White-flowered Fireweed). A beautiful white sport of the fireweed, which was found on one of our Vermont inountains. 1t spreads from creeping root stocks.

$\$ 0.60 \$ 1.75 \$ 12.00 \$ 100.00$

.60 $\quad 1.50 \quad 12.00 \quad 90.00$

$\begin{array}{llll}.60 & 1.50 & 12.00 & 110.00\end{array}$

$\left.\begin{array}{llll}.30 & 1.1\end{array}\right) \quad 8.00 \quad 60.00$

$\begin{array}{llll}.60 & 1.50 & 10.00 & 75.00\end{array}$

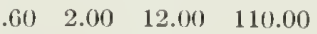

$.75 \quad 2.50 \quad \ldots \ldots \ldots$

$\begin{array}{llll}.60 & 1.50 & 12.00 & 100.00\end{array}$

$\begin{array}{llll}.60 & 1.50 & 12.00 & 100.00\end{array}$

$\begin{array}{llll}.60 & 1.75 & 12.00 \quad \ldots \ldots\end{array}$

$\begin{array}{llll}.60 & 2.00 & 15.00 & 135.00\end{array}$

1.5) $5.00 \quad 40.00$

$\begin{array}{llll}.60 & 1.50 & 10.00 & 90.00\end{array}$

1.50 


\section{Prices per}

ERYTHRONIUM albidum (White Troutlily). The easiest Troutlily to grow and a really worthwhile wild flower to plant in quantity.... with its yellow Lilylike blossoms in the Spring and the spotted leaves. californicum. A fine little Troutlily bearing several clear yellow blossoms on a stalk. Apparently the most easy to grow of the

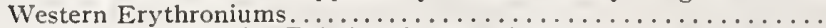
gigantea (Glacierlily). This is a large white Erythronium from the Western States, and is often called Glacierlily.

hendersoni (Henderson Troutlily). A delightful Erythronium from the Pacific coast, which seems to thrive well here in the East. It is

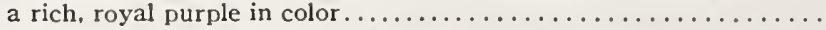

EUPATORIUM coelestinum (Mistflower). The flowers of the Mistflower are like beautiful blue Ageratum on $2 \mathrm{ft}$. stems. It likes the

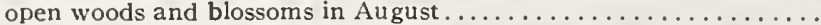

perfoliatum (Thoroughwort). A white flowered herb of the bogs,

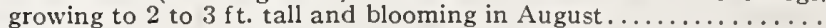

purpureum (Joe-pye-weed). Flower heads of rosy purple on 4 to $6 \mathrm{ft}$.

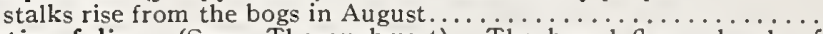

urticaefolium (Snow Thoroughwort). The broad flower heads of purest white blossom in August and September. This is one of the
finest plants for massing. It prefers a moist shade and grows 2 to $3 \mathrm{ft}$.

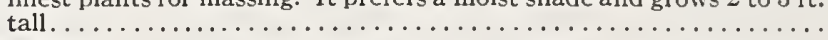

EUPHORBIA corollata (Flowering Spurge). Through the late Summer Euphorbia corollata is even better than Gypsophila Bristol Fairy to use in mixed bouquets, as it has stiffer stems. It grows naturally about $2 \mathrm{ft}$. tall in sandy fields or open woodlands ..............

FILIPENDULA rubra (Pink Spiraea). The wild pink Spiraea of the Central States. $2 \mathrm{ft}$. tall. July.....................

GALAX aphylla (Galax). This is a wild flower from the Southern Mountain, and thrives in the north in acid soil. The spikes of white flower in June. Evergreen leaves........................

GAULTHERIA procumbens (Checkerberry). A ground cover, used in partial shade or sun, with flowers like Blueberry blossoms. It

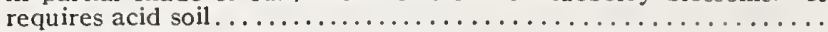

$0.50 \$ 1.00$

$\begin{array}{lll}.50 & 1.25 & 10.00\end{array}$

$\$ 60.00$

$.50 \quad 1.00$

$.50 \quad 1.00$

7.00

$.50 \quad 1.00$

7.00

$\begin{array}{lll}60 & 2.00 \quad 15.00\end{array}$

$\begin{array}{lll}.60 & 1.50 & 12.00\end{array}$

100.00

$.60 \quad 1.50$

$12.00 \quad 100.00$

$\begin{array}{lll}.60 & 1.50 & 10.00\end{array}$

80.00

$\begin{array}{llll}.60 & 1.50 & 12.00 & 100.00\end{array}$

$\begin{array}{lll}.60 & 2.00 \quad 15.00 \quad \ldots \ldots\end{array}$

$\begin{array}{llll}.60 & 2.00 & 15.00 & 135.00\end{array}$

$\begin{array}{llll}.60 & 1.50 & 12.00 & 100.00\end{array}$

$\begin{array}{llll}60 & 2.00 & 15.00 & 135.00\end{array}$

GENTIANA andrewsi (Blind Gentian). The blossoms of the Blind Gentian are the most intense blue of all wild flowers and is easily grown in moist shade or sun. It is $2 \mathrm{ft}$. tall and blossoms freely in

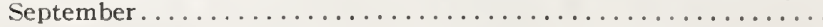

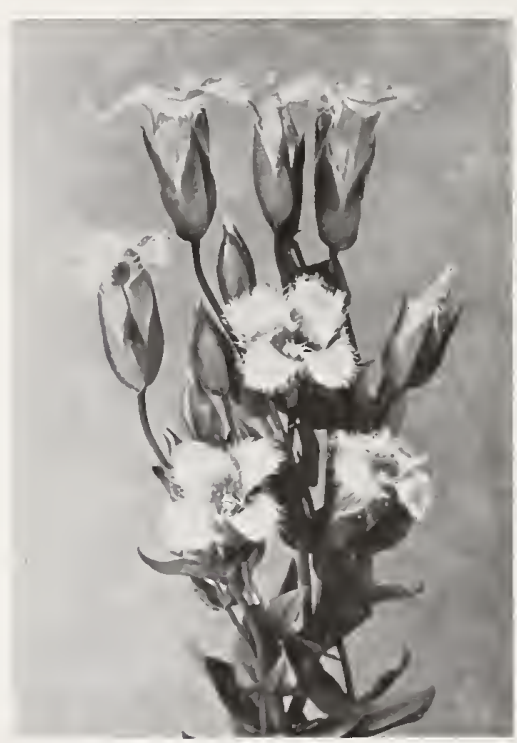

Gentiana crinita (Fringed Gentian) (See page 9)

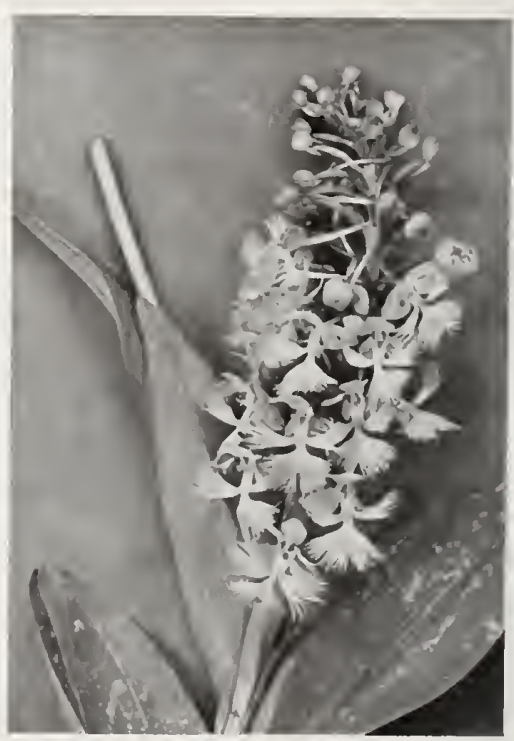

Habenaria fimbriata (Large Purple Fringeorchid) (Sce page 9) 


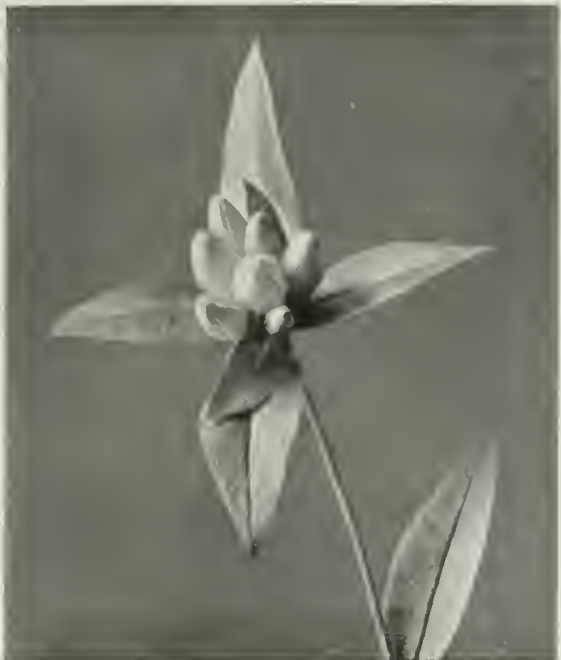

Gentiana andrewsi (Hlind Gentian) (See page 8)

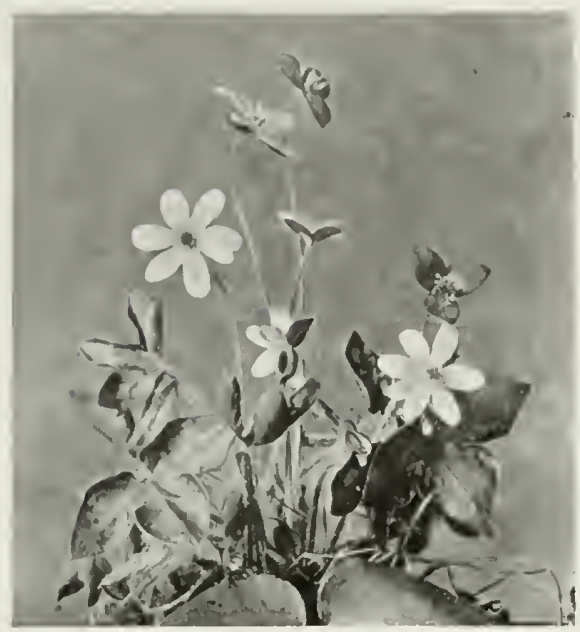

Hepatica acutiloba (Sharplobe Irepatica) (See page 10)

\section{GENTIANA - Continued}

\section{Prices per}

12

100

1000

crinita (Fringed Gentian). We won't try to describe the Fringed Gentian as everybody knows it and has hoped to have it some day. Again this year we have about 3000 plants to offer. Fringed Gentian will not thrive in acid leafmold, but should have a neutral or alkaline soil of muck and sand with plenty of moisture, but not where water stands in the Spring.

$\$ 1.50 \$ 5.00 \$ 40.00$

linearis (Narrow-leaved Gentian). Another Blind Gentian which blossoms six weeks earlier than the variety above, and with blossoms of porcelain blue.

GERANIUM maculatum (Wild Geranium). A native of the rocky woods, $1 \mathrm{ft}$. high, and bearing pink flowers in late Summer........

robertianum (Herb Robert). A Geranium with red stems and smaller flowers than the maculatum. This is also at home among the rocks.

GERARDIA virginica (Wild False Foxglove). The tall spikes of purest yellow resemble the cultivated Foxglove in shape. One of our most

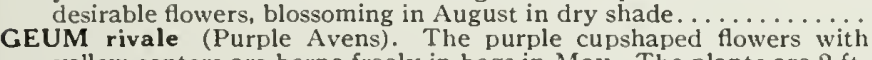
yellow centers are borne freely in bogs in May. The plants are $2 \mathrm{ft}$.

GOODYERA pubescens (Rattlesnake-plantain). Although the ${ }^{\text {tall }} \ddot{\mathrm{ft}}$. spikes of this white flowering orchid are attractive in August, it is the white veined, nearly prostrate leaves that make the Rattlesnakeplantain so desirable. It is at home in the pine woods...........

repens var. ophioides (Creeping Rattlesnake Plantain). A less common and more prostrate form of Goodyera than Goodyera pubescens. An inhabitant of the cold North woods...............

$.60 \quad 1.50 \$ 12.00 \$ 100.00$

$\begin{array}{llll}.60 & 1.50 & 12.00 & 100.00\end{array}$

$\begin{array}{llll}.50 & 1.25 & 10.00 & 75.00\end{array}$

$1.00 \quad 3.00 \quad 18.00 \quad \ldots \ldots$

$\begin{array}{lll}.60 & 1.50 & 10.00 \quad \ldots \ldots\end{array}$

$\begin{array}{llll}.60 & 2.00 & 15.00 & 135.00\end{array}$

$.60 \quad 2.00 \quad 15.00$

HABENARIA ciliaris (Yellow Fringe-orchid). In August, the orangeyellow flowers rise on 1 to $2 \mathrm{ft}$. flower stalks from the wet ineadows

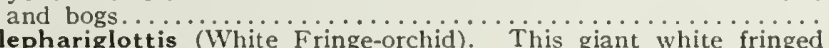

blephariglottis (White Fringe-orchid). This giant white fringed
Orchid is conspicuous in the mountain bogs in August. It is $2 \mathrm{ft}$. tall

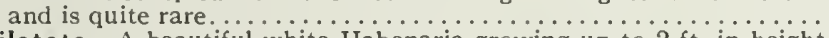

dilatata. A beautiful white Habenaria growing up to $2 \mathrm{ft}$. in height and blossoming in early Summer. . . . . . . . . . . . . . . . .

fimbriata (Large Purple Fringe-orchid). This seems to be our most desirable Orchid, due to its delightful fragrance and lavender pink color. A native of the bogs, growing to be $2 \mathrm{ft}$. tall.............. two immense round basal leaves of shining green, and blooms in July

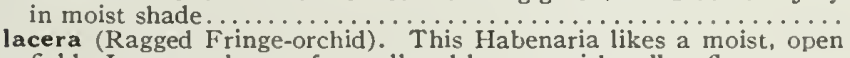
field. It grows about a foot tall and has greenish yellow flowers.... psycodes (Small Purple Fringe-orchid). It grows somewhat -maller
and paler than the fimbriata, and with a most elusive fragrance in

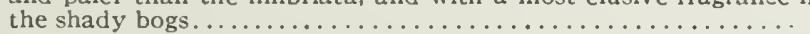

$5.00 \quad 35.00$

$\begin{array}{lll}1.50 & 5.00 \quad 35.00\end{array}$

$\begin{array}{lll}1.00 & 3.50 \quad 28.00\end{array}$

\section{$1.00 \quad 3.50 \quad 28.00 \quad 250.00$}

$1.00 \quad 3.50 \quad 28.00 \quad \ldots \ldots$

$.60 \quad 2.50 \quad \ldots \ldots \ldots$

$\begin{array}{llll}1.00 & 3.50 & 28.00 \quad 250.00\end{array}$ 


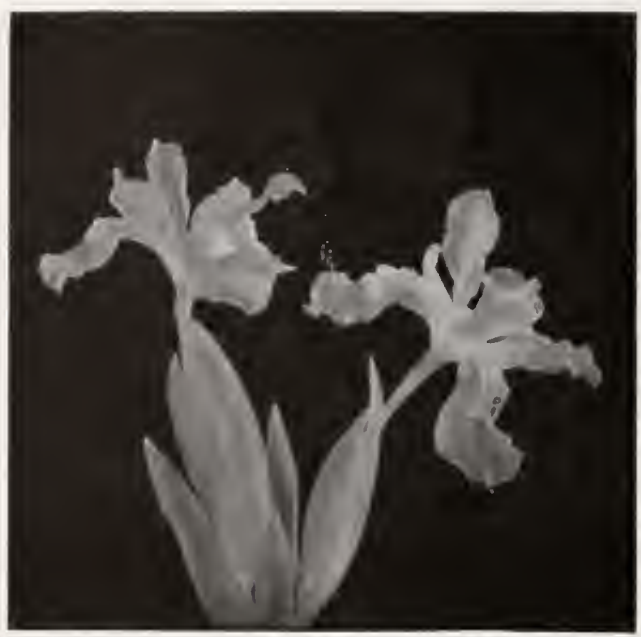

Iris cristata (Crested Iris)

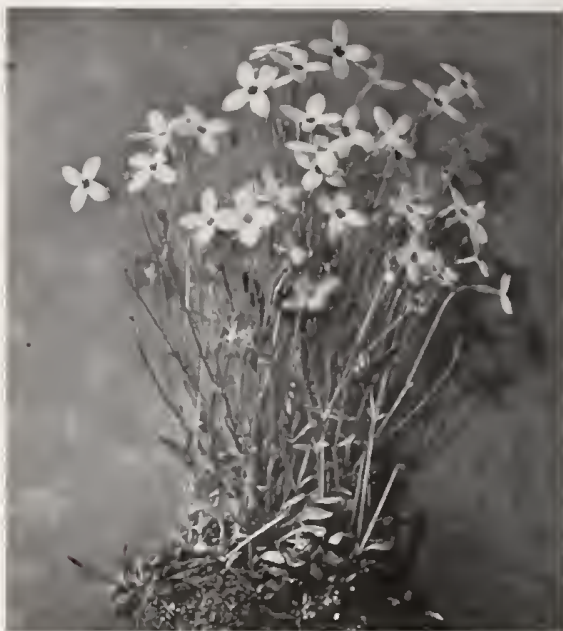

Houstonia caerulea (Quaker Ladies)

Prices per 3

12

100

1000

HELENIUM autumnale (Sneezeweed). A bright yellow Helenium from the South, producing its 3 to $4 \mathrm{ft}$. flower stems in August and

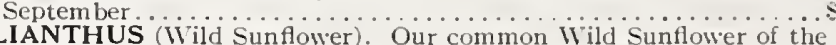

HELIANTHUS (Wild Sunflower). Our common Wild Sunflower of the
roadsides and woods adds gaiety to the late Summer and Autumn. divaricatus (Woodland Sunflower). A rather delicate Sunflower from 2 to $4 \mathrm{ft}$. tall, which lacks the coarse appearance of most of our Sunflowers....

HEPATICA acutiloba (Sharplobe Hepatica). This has evergreen foliage. The color of the blossoms varies from white to pink and purple. It is indispensable for rich woods. It is about 8 in. tall and blossoms

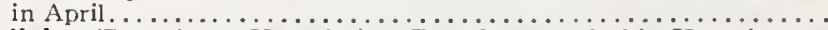

triloba (Roundlobe Hepatica). The flowers of this Hepatica are mostly pale blue or white. It prefers slightly acid soil and shade, but is not so strong a grower as the sharplobe Hepatica.

HOUSTONIA caerulea (Quaker Ladies). This dainty little plant with blue and white blossoms is a biennial and should be planted in the open sun or partial shade for blossoms the following Spring. It grows 3 to 4 in. tall.

HYDRASTIS canadensis (Goldenseal) This is a pant o medicinal fame, its value is due more to its romantic history than its actual beauty.

HYDROPHYLLUM virginianum (Waterleaf). A plant growing $1 \mathrm{ft}$. high, with purplish white flowers blossoming in Midsummer in moist

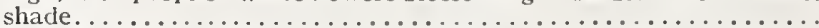

HXPOXIS hirsuta (The Jellow Stargrass). A tiny jollow companion for the Blue-eyed Grass, growing in ficlds and open thickets. It blossoms in May and June...

INULA helenium (Elecampane) The open fields are the homes of this Elecampane, with its Sunflowerlike flowers blossoming in Midsum-

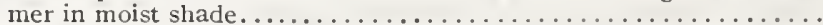

IRIS cristata (Crested Iris). Sky blue flowers on 4 in. stems. This is fine plant for rock gardens, and grows in either sun or shade.....

cristata alba (White Crested Iris). One of our rarest native plants. Sold in single divisions............................ $\$ 1.50$

prismatica (Cubeseed Iris). A native New England waterside plant

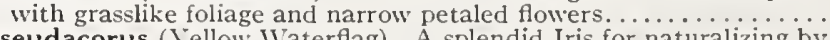

pseudacorus (Yellow Waterflag). A splendid Iris for naturalizing by ponds and streains, but will grow anywhere. The flowers resemble those of a golden yellow Japanesc Iris. It grows 2 to $4 \mathrm{ft}$. in height

and blossoms in June............................................ (Vernal Iris). Charmingly modest, the sky blue Iris verna are most at home in the dry woods or in the rockery. It

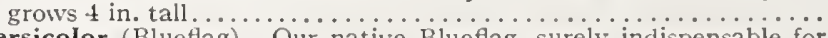

versicolor (Blueflag). Our native Blueflag, surely indispensable for

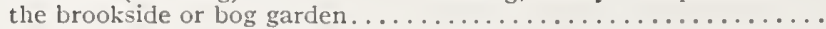

$\$ 90.00$

$\begin{array}{llll}.60 & 1.50 & 9.00 \quad 75.00\end{array}$

$.60 \quad 2.00 \quad 15.00$

$\begin{array}{llll}60 & 1.75 & 12.00 & 100.00\end{array}$

$\begin{array}{llll}.60 & 1.75 & 12.00 & 100.00\end{array}$

$\begin{array}{llll}60 & 1.50 & 8.00 \quad 60.00\end{array}$

$.60 \quad 2.00 \quad \ldots \ldots \ldots \ldots$

$\begin{array}{llll}.60 & 1.50 & 12.00 & 100.00\end{array}$

$.60 \quad 2.00 \quad 15.00 \quad \ldots \ldots$

$.60 \quad 2.00 \quad 15.00 \quad \ldots \ldots$

$\begin{array}{llll}.60 & 2.00 & 15.00 & 125.00\end{array}$

$\begin{array}{llll}60 & 1.50 & 12.00 & 100.00\end{array}$

$\begin{array}{llll}.90 & 2.50 & 16.00 & 140.00\end{array}$

$\begin{array}{llll}.90 & 2.50 & 15.00 & 135.00\end{array}$

$\begin{array}{llll}60 & 1.50 & 10.00 & \$ 0.00\end{array}$ 
ISOP YRUM biternatum (False Rue Anemone). Common in the moist thickets from Minnesota and Southward. This plant bears white petal-less flowers in early Spring.

$\$ 0.60 \$ 1.75 \$ 12.00$

JEFFERSONla diphylla (Twinleaf). A Spring flowering plant, growing 6.12 in. high. The blossons are white, similar to llepaticas....

LEUCOCRINIUM montanum (Colorado Sand l,ily). A tiny, little plant whose fragiant white flower clusters are borne early in the

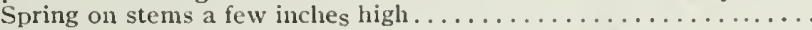

LEWISI A rediviva (Bitterroot). This state flower of Montana succeeds well on the open, sandy soil in the East. The large, pale pink or white blossoms look inuch like IVaterlily blossoms set on the sand.......

LIATRIS pycnostachys (Cattail Gayfeather). This tallest of the Gayfeat hers grows to about $3 \mathrm{ft}$. or more in height and exhibits deen pink blossoms in August

scariosa (13utton Gayfeatler). The Button Gayfeather grows only $2 \mathrm{ft}$. tall and the buttonlike flowers are produced in Midsummer

spicata (Spike Gayfeather). This Gayfeatler is best known for the beauty of its spikes which are deep rose and attain a height of $21 / 2 \mathrm{ft}$. All Gayfeathers are crazy, for instead of starting to blossom at the bottom of the spikes like other flowers, they start at the top and blossom downward.

LILIUM canadense (Meadow 1,ily). If any plants are necessary for successful naturalistic planting, they are the wild Lilies. As its name suggests, the Mleadow Lily prefers the rich, moist meadows and in July, its blossoms vary from pale yellow to red and are most attrac-

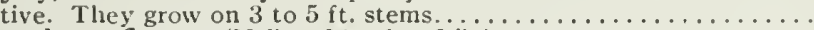
canadense flavum (Yellow Meadow Lily)..................

carolinianum (Carolina Lily). A very fragrant Lily with orange colored flowers. 1t grows from 3 to $4 \mathrm{ft}$. in height and blossoms in

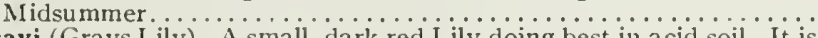
grayi (Grays Lily). A small, dark red Lily doing best in acid soil. It is the darkest colored of our native Lilies......................... pardalinum (Leopard Bog Lily). From the Pacific Coast. Orange scarlet and brown, growing naturally on hummocks in bogs.......

philadelphicum (Wood Lily). The brilliant splashes of red among
the Sweet Fern and Blueberry bushes is accounted for by the Wood Lily. $1 \mathrm{t}$ grows best in acid soil and attains a height of $2 \mathrm{ft} \ldots \ldots \ldots$ superbum (Turkscap Lily). The tallest native Lily, growing $5 \mathrm{ft}$. high and producing its orange colored blossoms profusely in the meadows or partial shade in July.

$.60 \quad 2.00 \quad 15.00$

$60 \quad 2.00 \quad 15.00$

$.75 \quad 2.50 \quad 18.00$

$.60 \quad 2.00 \quad 15.00$

$.50 \quad 1.50 \quad 10.00$

$\$ \$ 000$

$.60 \quad 2.00 \quad 12.00$

100.00

$\begin{array}{llll}.60 & 2.00 & 12.00 & 100.00\end{array}$

$\begin{array}{llll}.90 & 3.00 & 20.00 & 175.00\end{array}$

$1.00 \quad 2.75$

$.75 \quad 2.50$

20.00

175.00

$1.50 \quad 5.00$

.602 .00

15.00

120.00

LINAR I A vulgaris (Butter-and-eggs). A plant that is easily grown in light open soil and blossoms in June and July. The blossoms are like yellow Snapdragons.

LINNAEA americana (Twinflower). The dainty pink flowers of this plant are borne on prostrate vines. To appreciate the beauty of the Twinflower one slould see it completely covering a rotten log with

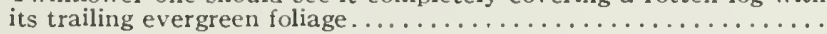

LIPARIS liliifolia (Lily Twayblade). A little Orclid of the swamps growing 6-8 in. tall with loose racemes of delicate Orclid colored

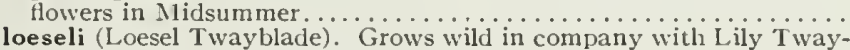
blade but with yellowish green flowers..................... of the Middle States. Puccoon is $6-18$ in. tall. 1 t has yellow flowers borne in clusters in May and June.

$.60 \quad 1.50 \quad 8.00$

60.00

\section{$\begin{array}{lll}75 & 2.50 & 18.00\end{array}$}

$1.00 \quad 3.00$

1.003 .00

.60 $1.75 \quad 12.00$

LOBELIA cardinalis (Cardinalflower). This vivid scarlet flower for brooks and ponds should be planted where the ground does not freeze. 1t blossoms in August and grows to be 1 to $2 \mathrm{ft}$. tall

spicata (Common Blue Lobelia). A plant which blossoms in July and August growing from 1 to $2 \mathrm{ft}$. tall in the open fields and pastures..

syphilitica (Large Blue Lobelia). This large blue Lobelia corresponds closely to the Cardinalflower except that the blossoms are blue in color.

LYSIMACHIA nummularia (Moneywort). Moneywort has made itself so thoroughly at home in this country that it is considered a native plant. It is a very useful ground cover for dry banks. The attractive yellow flowers are borne in July .................

quadrifolia (Whorled Loosestrife). In July, tle bogs are gay with this

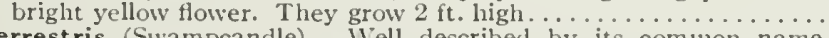

terrestris (Swampcandle). Well described by its cominon name. Bright yellow candles on 2 in. sticks. Blossons in bogs in late

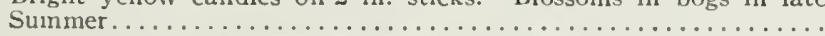

$\begin{array}{llll}.60 & 2.00 & 13.50 & 120.00\end{array}$

$\begin{array}{llll}.50 & 1.50 & 10.00 & 75.00\end{array}$

.60 $\quad 2.00 \quad 13.50 \quad 120.00$

$\begin{array}{llll}60 & 1.75 & 12.00 & 100.00\end{array}$

$\begin{array}{llll}60 & 1.50 & 10.00 & 90.00\end{array}$

$\begin{array}{lll}60 & 2.00 & 15.00\end{array}$ 


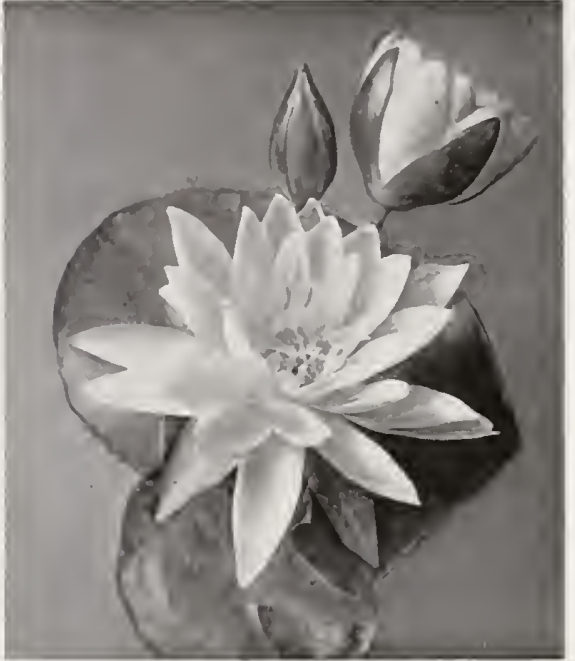

Nymphaea odorata (White Waterlily) (See page 13)

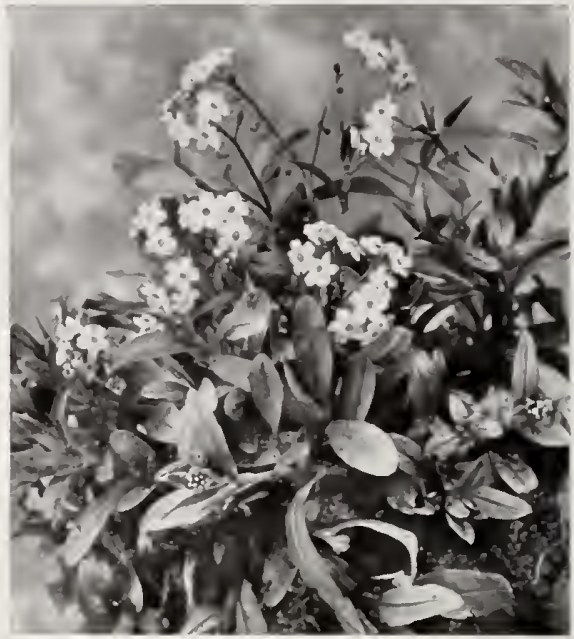

Myosotis scorpioides (True Forget-me-not) (See page 13)

Prices per

12

100

1000

LYTHRUM salicaria roseum (Purple Loosestrife). A naturalized immigrant that brightens the bogs and meadows in July and August. It grows from 2 to $3 \mathrm{ft}$ tall.......................... $\$ 0.60 \$ 1.75 \$ 12.00 \$ 100.00$

MAIANTHEMUM canadensis (Canadian Mayflower or Wild Lily-ofthe-valley). A very beautiful wild flower native to the dry woods of the North. The spikes of fluffy white, fragrant flowers attain a height of about 4 in. and are borne about the last of May, followed

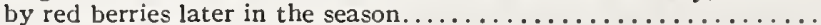

MEDEOLA virginica (Cucumber-root). The greenish yellow flowers of the Cucumber-root are borne on 1 to $2 \mathrm{ft}$. stems and are followed by blue berries in the Summer, but the curious whorled leaves and white fleshy root which resembles Cucumber in flavor are what attract the most attention to this plant..................

MENTHA peperita (Peppermint). We believe it is unnecessary to describe this plant, but every one should have it for the brookside. . spicata (Spearmint). The flavor at least of the Spearmint is known to all Americans, if the plant itself is not, but it is an attractive waterside plant and the leaves are useful for many purposes..........

MERTENSIA virginica (Virginia Bluebells). This plant, with its nodding bluebells, blossoming pink and turning to the clearest blue is one of the most desirable Spring blossoming plants for sun or shade. It should be planted in masses for the best effect. We sell more of this

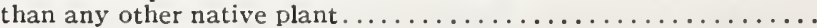

MIMULUS ringens (Monkeyflower). On stems from 1 to $2 \mathrm{ft}$. tall, the grinning blue Monkeyflowers grow in bogs and wet ground

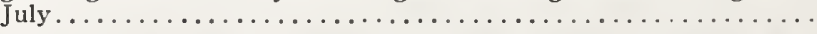

MITCHELLA repens (Partridgeberry). This is much in demand as a prostrate ground cover for shady places, but the foliage is not the only attractive feature, because the pink and white blossoms in Summer and scarlet berries in the Fall receive their share of

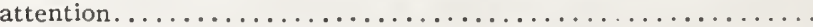

$\begin{array}{lll}60 & 1.50 & 10.00 \quad \$ 0.00\end{array}$

$\begin{array}{llll}.50 & 1.50 & 10.00 & 75.00 \\ .60 & 1.75 & 12.00 & 100.00 \\ & & & \\ .60 & 1.75 & 12.00 & 100.00\end{array}$

$.60 \quad 1.50 \quad 10.00 \quad 75.00$

$\begin{array}{llll}60 & 2.00 & 15.00 & 120.00\end{array}$

$\begin{array}{llll}60 & 2.00 & 12.00 & 110.00\end{array}$

MITELLA diphylla (Mitrewort). The white flower stems of the Bishopscap are at home in the shady rock garden. They are $1 \mathrm{ft}$. tall

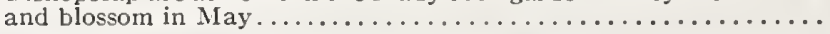

MONARDA didyma (Wildbergamot) (Beebalm). Making brilliant patches of scarlet in Midsummer, the Beebalm grows from 1 to $2 \mathrm{ft}$.

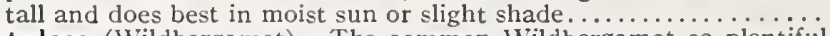

fistulosa (Wildbergamot). The common Wildbergamot so plentiful throughout the Eastern United States and Canada. It grows $2 \mathrm{ft}$. tall and bears pale purple blossoms. It blooms in Midsummer.... 


\section{MONESES Price for}

(One-flowered Py-

rola). A plant

with beautiful sin-

gle white, waxy

flowers on a 4-6

in. stem, which

blossoms in June.

The Pyrolas are

hard to establish

and failures in

transplanting are

very common. . . \$0.60 \$2.00 $\$ 15.00$

MYOSOTIS scorpi-

oides (True lior-

get-me-not). Of

all the plants for

the brookside

planting, none is more daintily attractive than the

True Forget-menot. It blossoms throughout the the Summer.....

12

100

1000

$\begin{array}{lll}.60 & 1.75 & 12.00 \$ 100.00\end{array}$

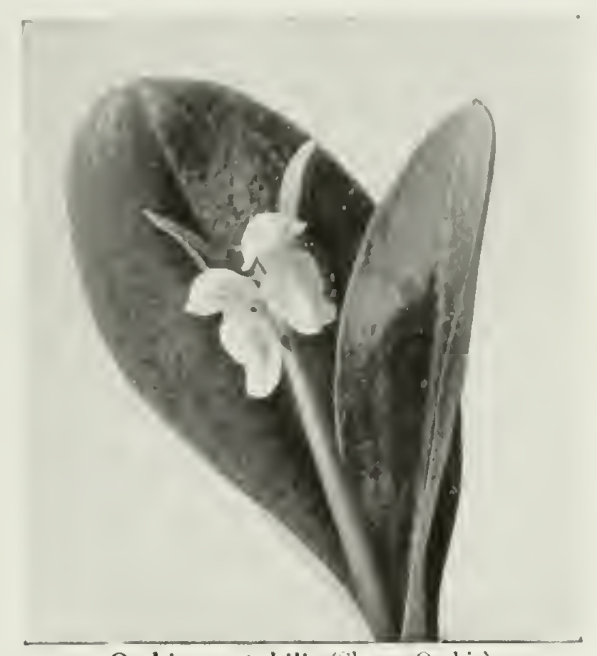

NUPHAR advena (Cowlily). A yellow Waterlily whicl grows Prices per $3 \quad 12 \quad 100$ in the still ponds and blossoms in Midsummer.

NYMPHAEA odorata (White Waterlily). The queen of all water plants. Our native Waterlily is best described by the illustration on page 12.

OAKESIA sessifolia (Wild Oats). The drooping, creamy white bells of the Wild Oats are found along the fences and in the open meadows in

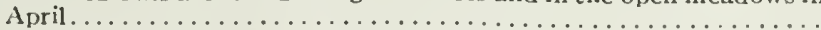

$\begin{array}{llll}.75 & 2.50 & 18.00 & 150.00\end{array}$

$\begin{array}{llll}.50 & 1.50 & 8.00 & 60.00\end{array}$

$\begin{array}{llll}.60 & 2.00 & 15.00 & 135.00\end{array}$ across. It blossoms in June and July and requires full sun.ers, 2 in.

ORCHIS spectabilis (Showy Orchis). Lovely and fragrant, the white and lavender flowers of the Showy Orchis add to the beauty of the

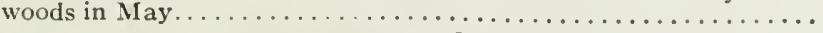

OXALIS violacea (Woodsorrel). The dainty pink flowers and three parted leaves of the Woodsorrel typify fragility. The plant grows only 3 to 4 in. tall and flowers in June and July in the moist woods...

PANAX quinquefolium (Ginseng). This is the Ginseng of commerce. Its flowers are green ish white and the fruit bright red. When it grows wild, it is found in the company of Butternut trees..........

trifolium (Dwarf Ginseng or Groundnut). A tiny little Ginseng growing only 3-4 ft. tall and with very airy, white fluffy blossoms during the Spring

PARNASSIA caroliniana (Grass of Parnassus). The white Anemonelike flowers of the Grass of Parnassus, on 12 in. stems enliven the sunny bogs in early Fall..

PEDICULARIS canadensis

(Woodbetony). A curious plant with brown and yellow flowers and raggedy leaves. It grows by the roadside and dry woods and blossoms in June.... . $\begin{array}{llll}1.00 & 3.50 \quad 28.00 & 250.00\end{array}$
80.00 $\begin{array}{lll}.60 & 1.50 \quad 10.00\end{array}$

$\begin{array}{lll}.60 & 1.75 & 12.00\end{array}$

100.00
Pentstemon digitalis (Foxglove Pentstemon) (See page 14) $\begin{array}{lll}.50 & 1.50 \quad 10.00\end{array}$

$\begin{array}{lll}.60 & 2.00 \quad 15.00\end{array}$

This price list is for Fall, 1932 only and does not apply to orders for Spring, 1933 


\section{Prices per $\begin{array}{llll}3 & 12 & 100 & 1000\end{array}$}

PENTSTEMON barbatus. This might well be called Fire Cracker plant because the individual flowers on $2 \mathrm{ft}$. stems resemble fire crackers in shape and color and are always in bloom by July 4 th ............... digitalis (Foxglove Pentstemon). A pure white Pentstemon which grows $2 \mathrm{ft}$. tall and blossoms in Midsummer in the open sun....... tall, with lovely lavender pink flowers from May to July: .

$0.60 \$ 2.00 \$ 15.00 \$ 135.00$

$\begin{array}{llll}.60 & 1.75 & 12.00 & 100.00\end{array}$

$75 \quad 2.50$

PHLOX amoena (Amoena Phlox). A low-growing pink Phlox from the South at a distance resembling Phlox subulata, but growing in neater more compact tufts. For light, open soil .

divaricata (Blue Phlox). For woodland massing no plant excels the Blue Phlox. When once established it seeds freely .............

pilosa (Downy Phlox). This is a contribution from the middle west. The lovely pink flowers blossom in June and grow $1 \mathrm{ft}$. tall........

reptans. This creeping Phlox should be more generally used, for it is one of the best low growing plants for the dry woods. Large pink

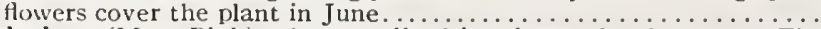
subulata (Moss Pink). A naturalized immigrant for dry sun. The

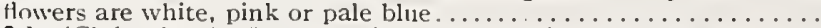

bifida (Cleft Phlox). Low growing Phlox $3-6$ in tall from the sandy lands of the Central West. Color is usually pale purple.........

glaberrima (Smooth Phlox). Prairie Phlox growing 1-3 ft. high and

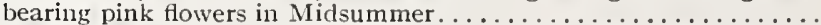

ovata (Mountain Phlox). One of the most attractive wild Phlox for sun or shade. It is about $1 \mathrm{ft}$. tall and covered with beautiful pink flowers in June. A native of the Southern Mountains and a welcome plant in formal border and naturalistic plantings.............

PHYSOSTEGIA speciosa (False-dragonhead). The swamps of the eastern states have contributed this plant to our gardens, where it is well known. It grows $2 \mathrm{ft}$. tall and has spikes of Snapdragonlike flowers of pink. It stays in bloom a long time..............

PHYTOLACCA americana (Pokeweed). This plant has white flowers in July and dark red berries in September. It prefers to grow on the

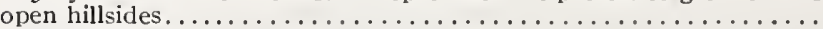

PODOPHYLLUM peltatum (Mayapple). Everyone associates the Mayapple with school days. It is a native of the open woods and grows $1 \mathrm{ft}$. tall. The white flowers in May are followed by yellow

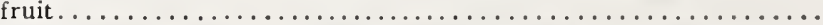

POGONIA ophiglossoides (Rose Pogonia). One of our smallest native Orchids found growing in swamps. The blossoms are lovely lavender pink in color, coming in June and July. It grows only 6 in. tall. The shape of the blossoms is such that it is often called by the ill

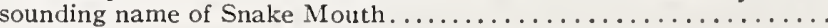

POLEMONIUM reptans (Greek-valerian). A plant with blue flowers in May, used for rock gardens. They grow to $1 \mathrm{ft}$. in height.....

POLYGALA paucifolia (Fringed Polygala). The lavender flowers rise in May on 6 in. stems from the creeping root stalks. They prefer

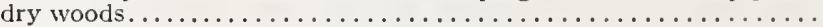

POLYGONATUM biflorum (Solomonseal). Green bells are spaced along the underside of the 12 to 18 in. stalks in Spring and are followed by bright blue berries. This plant prefers woods

commutatum (Great Solomonseal). This must be the grandfather of all Solomonseals, because it grows 3 or $4 \mathrm{ft}$. tall, in the open moist fields.

PONTEDERIA cordata (Pickerelweed). The roots grow under shallow water. It has large attractive leaves and blue flower spikes in July. .

POTENTILLA tridentata (Wineleaf Cinquefoil). A low, shrubby perennial from exposed, gravelly locations along the northeastern Atlantic coast. Attractive solitary white flowers in Midsummer...

$\begin{array}{lll}.60 & 2.00 \quad 15.00\end{array}$

$\begin{array}{llll}60 & 1.75 & 12.00 & 100.00\end{array}$

$\begin{array}{llll}60 & 1.75 & 12.00 & 100.00\end{array}$

$\begin{array}{llll}60 & 1.75 & 12.00 & 100.00\end{array}$

$\begin{array}{llll}60 & 2.00 & 15.00 & 120.00\end{array}$

$\begin{array}{llll}60 & 1.75 & 12.00 & 100.00\end{array}$

$\begin{array}{llll}60 & 1.75 & 12.00 & 100.00\end{array}$

$\begin{array}{llll}.60 & 2.00 & 15.00 & 120.00\end{array}$

$\begin{array}{llll}60 & 2.00 & 15.00 & 135.00\end{array}$

$\begin{array}{llll}60 & 1.50 & 12.00 & 100.00\end{array}$

$\begin{array}{llll}.60 & 1.75 & 12.00 & 100.00\end{array}$

$\begin{array}{llll}75 & 2.50 & 18.00 & 150.00\end{array}$

$\begin{array}{llll}.60 & 2.00 & 15.00 & 135.00\end{array}$

$\begin{array}{llll}.75 & 2.50 & 18.00 & 150.00\end{array}$

$\begin{array}{llll}.60 & 2.00 & 13.50 & 110.00\end{array}$

$\begin{array}{llll}.60 & 2.00 & 15.00 & 125.00\end{array}$

$\begin{array}{llll}.60 & 1.75 & 12.00 & 100.00\end{array}$

$1.00 \quad 3.00 \quad 15.00$

PYROLA americana (Roundleaf Pyrola). The fragrant, waxy cupshaped flowers of the Roundleaf Pyrola are borne on $8 \mathrm{in}$. stems in July. It has evergreen leaves and prefers to grow in hardwood sliade. Pyrolas do not transplant easily..

elliptica (Shinleaf). The blossons of the Shinleaf closely resemble those of the Roundleaf Pyrola, but the leaves are not evergreen. Both Pyrolas are very fragrant. .

RANUNCULUS bulbosa (Bulbous Buttercup). A large flowering Buttercup growing from bulbs. It has a compact growtl and is used for sunny rock gardens. It grows $1 \mathrm{ft}$. tall and blossoms in June and

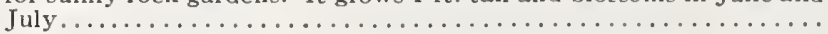




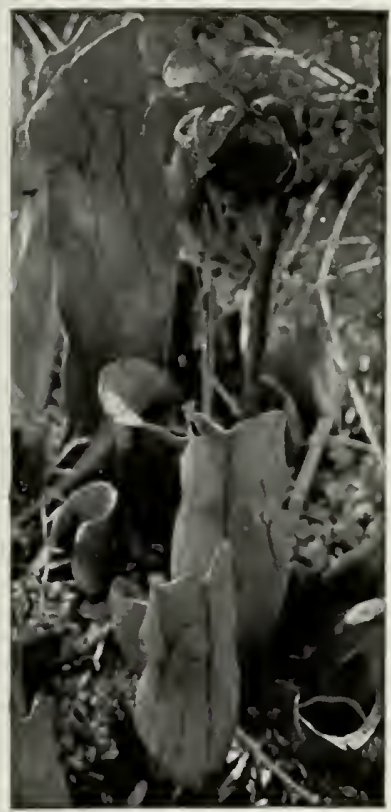

Sarracenia purpurea

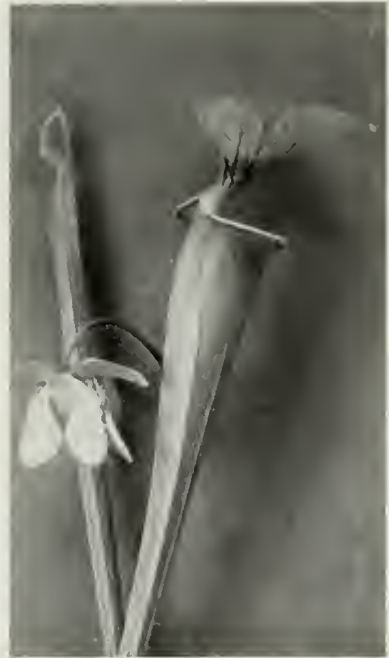

Sarracenia flava (Trumpet Pitcherplant)

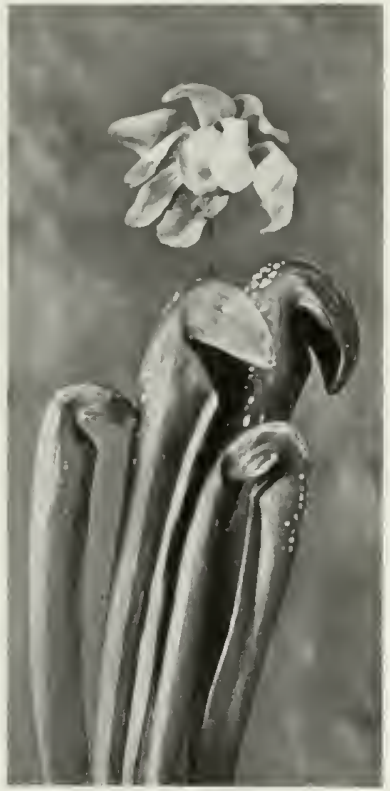

Sarracenia minor (Hooded Pitcherplant)

RANUNCULUS-Continued

\section{Prices per 3}

12

100

1000

repens (Creeping Buttercup). A creeping variety of Buttercup introduced from Europe, but naturalized here. The blossoms are very double. It likes moist ground and is about a foot tall. .........

RUDBECKIA newmanni. A Western Black-eyed-susan, very much like our common one, except that it is a perennial instead of a biennial

SAGITTARIA Iatifolia (Arrowhead). The leaves of this Arrowhead are arrowshaped and the blossoms are white on $2 \mathrm{ft}$. stems. It enriches the beauty of the shallow ponds and bogs in Midsummer... .

SALVIA azurea (Azure Salvia). A beautiful contribution from the Rocky Mountains, growing from 2 to $3 \mathrm{ft}$. tall. The sky blue blossoms are borne over several weeks in late Summer............

SANGUINARIA canadensis (Bloodroot). One of our finest, pure white early Spring flowers growing in sun or shade and about 8 in. tall...

SANGUISORBA canadensis (American Burnet), An unusual and picturesque plant found growing naturally among the stones on the banks of small rivers. Spikes of creamy white rise to a height

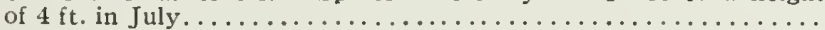

SARRACENIA flava (Trumpet Pitcherplant). This is from the South and has elongated pitchers $2 \mathrm{ft}$. tall. The flowers are yellow; a very

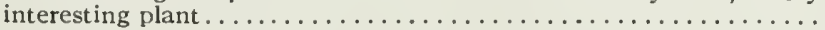

minor (Hooded Pitcherplant). A very peculiar Pitcherplant from the South. The trumpetlike pitchers wear a lood like a Jack-in-the-

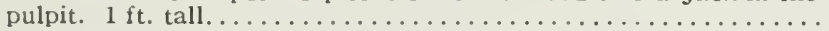

purpurea (Pitcherplant). This is a red-flowered Pitcherplant with 12 to $18 \mathrm{in}$. stems and pitcherlike leaves which catch insects and

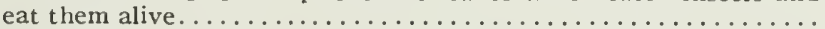
rubra (Red Pitcherplant). A small-growing Pitclierplant of the

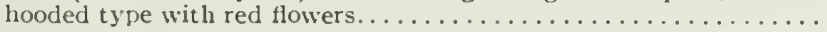

SAXIFRAGA pennsylvanicum (Swamp Saxifrage). Imagine Mignonette blossoms growing on $3 \mathrm{ft}$. stems in the swamps in late May and

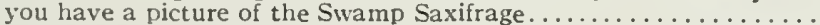

virginiensis (Mountain Saxifrage). A beautiful native rock plant which clings to the ledges and likes either sun or partial shade.

$\begin{array}{llll}.60 & 1.50 & 10.00 & 90.00\end{array}$

$\begin{array}{llll}60 & 2.00 & 15.00 & 135.00\end{array}$

$\begin{array}{llll}.60 & 1.50 & 10.00 & 75.00\end{array}$

$\begin{array}{llll}.75 & 2.50 & 18.00 & 140.00\end{array}$

$\begin{array}{llll}.75 & 2.50 & 18.00 & 140.00\end{array}$

$\begin{array}{llll}.60 & 2.00 & 15.00 & 135.00\end{array}$

$.75 \quad 2.50$

$\begin{array}{llll}.60 & 2.00 & 15.00 & 135.00\end{array}$

$\begin{array}{llll}.60 & 1.75 & 12.00 & 100.00\end{array}$ 


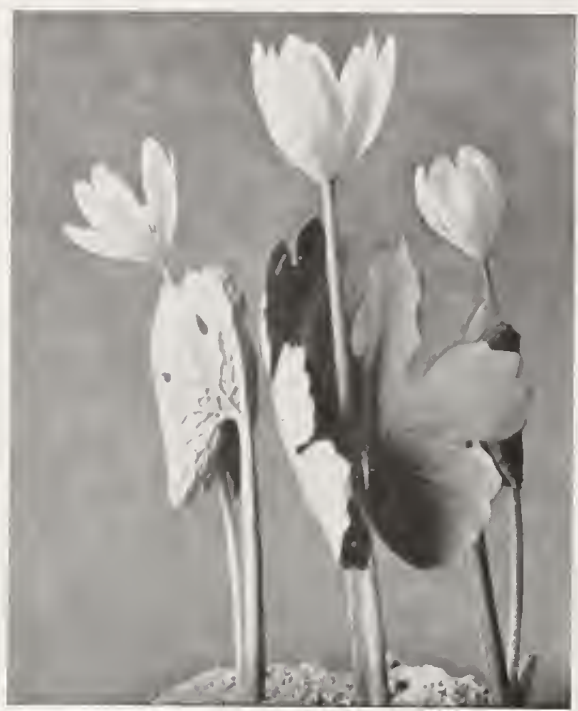

Sanguinaria canadensis (Bloodroot) (See page 15)

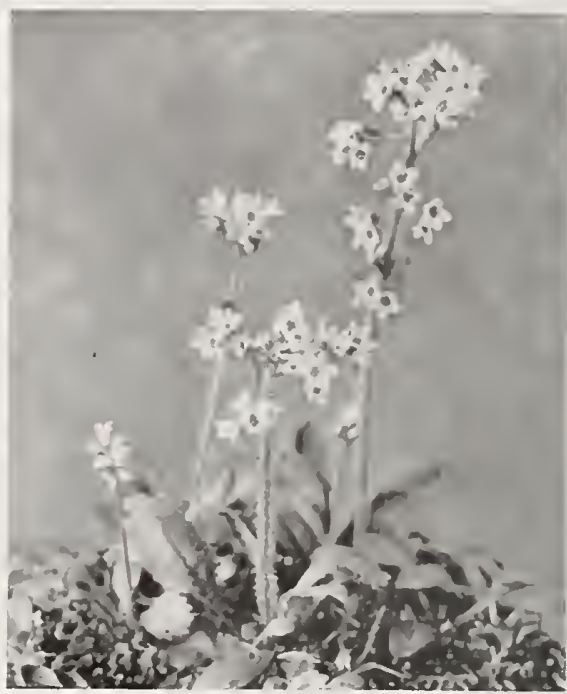

Saxifraga virginiensis (See page 15)

\section{Prices per $3 \quad 12 \quad 100$}

1000

SCIRPUS atrovirens (Sedge). A tall growing, picturesque sedge for the borders of ponds and bogs....................... $\$ 0.60 \$ 1.50 \$ 10.00$

SCUTELLARIA integrifolia (Skullcap). Somewhat similar to the Monkeyflower. It grows about the same height and blossoms in Midsummer. Flowers in the axils of the leaves. For marshy ground.

$\begin{array}{lll}60 & 1.75 & 12.00 \quad \ldots \ldots\end{array}$

SENECIO aureus (Golden Ragwort). A Ragwort of a most gorgeous color that enlivens the bogs with flame in late May. It grows about

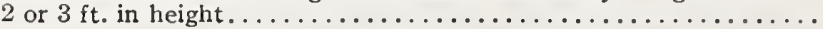

SHORTIA galacifolia (Oconee-bells). An evergreen ground cover with very attractive, bell-shaped white flowers on 6 in. stems........

SILENE pennsyIvanica (Peatpink). A choice little plant from the dry, rocky soil of the Appalachian states, about 6 in. tall, with bright pink flowers an inch broad in terminal clusters......................
stellata (Starry Campion). This plant has prettily fringed white

flowers in June. It likes sun and grows about $2 \mathrm{ft}$. tall.j............
virginica (Firepink). The flowers of the Firepink are brilliantly scarlet, coming in June. The plant likes either sun or open woods....

SILPHIUM perfoliatium (Cup Rosinweed). Tall, rather coarse plant of the Elecampagne type. From the Central West. It has Sunflower-

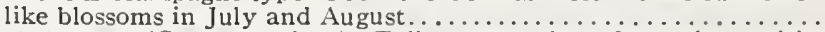

laciniatum (Compass plant). Tall, coarse plant from the prairies, with yellow, Daisylike flowers in Midsummer. It derives its name from the fact that the vertical leaves present their edges North and

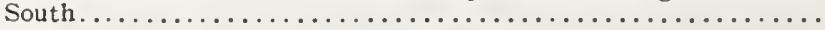

SISYRINCHIUM angustifolium (Blue-eyed-grass). The Blue-eyedgrass might be mistaken for the tiniest of all Iris. It does best in full

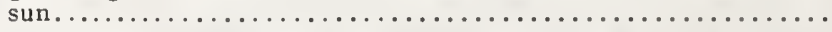

SMILACINA racemosa (False Solomonseal). The white flowered plant of the False Solomonseal in May has red, glassy berries later. It

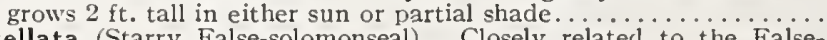

stellata (Starry False-solomonseal). Closely related to the Falsesolomonseal, but has larger and fewer flowers in a cluster.........

$\begin{array}{rrrr}.60 & 2.00 & 15.00 & 135.00 \\ .60 & 1.50 & 10.00 & \ldots \ldots\end{array}$

SOLANUM dulcamara (Climbing or Bitter Nightshade). A lovely vine introduced from Europe, but is so thoroughly naturalized that it may be considered native to our Eastern States. It is usually found along the brooks. The purple blossoms in June and July, followed by red berries in September, make it a particularly attractive plant for naturalistic plantings. This is not the deadly Nightshade......... 


\section{Prices per $3 \quad 12 \quad 100$}

1000

SOLIDAGO (Goldenrod) Mixed Varieties. We offer this for our Euro-

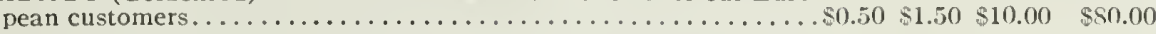

odora (Fragrant Goldenrod). A small-growing Goldenrod with almost evergreen leaves, which when crushed emit the delightful fragrance of anise. 1t delights in the acid soil underneath Oak trees.

SPATHYEMA foetida (Skunkcabbage). One of our earliest flowers to bloom, the greenish round flowers arriving in the earliest Spring. The plant lias immense leaves and grows well in shady bogs...... $8 \mathrm{in}$. twisted spikes of white, very fragrant flowers and is at home

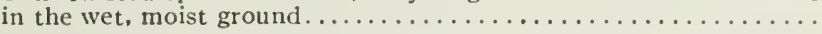

STEIRONEMA siliatum (I,oosestrife). Closely allied to the Lysimachia, but with larger, more separated yellow flowers. Blossoms from June to August in moist woods or thickets...............

STREPTOPUS amplexifolium. A tall growing, twisted stalk, sometimes reaching $3 \mathrm{ft}$. in height and bearing its brilliant, fruitlike scarlet Solomonseal three weeks later than Streptopus roseus. Preferring

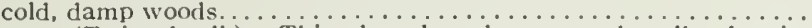

roseus (Twistedstalk). This plant has three parted stalks, bearing dainty pink bells in May and gorgeous scarlet herries late in july. It grows $2 \mathrm{ft}$. tall and is decidedly attractive in any wild garden where there is rich soil and partial shade.

$\begin{array}{lll}60 & 2.00 \quad 15.00\end{array}$

$\begin{array}{llll}75 & 2.50 & 16.00 & 135.00\end{array}$

$.60 \quad 2.00 \quad 15.00$

$.75 \quad 2.50 \quad 18.00 \quad \ldots \ldots$

$\begin{array}{llll}60 & 2.00 & 15.00 & 135.00\end{array}$

STYLOPHYLLUM diphyllum (Celandine). A most easily grown buttercuplike flower, $2 \mathrm{ft}$. tall, for sun or shade, and blossoming in

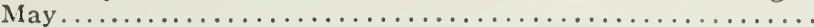

THALICTRUM dioicum (Early Meadowrue). A Thalictrum with misty purplish flowers in May and attractive foliage. It grows $2 \mathrm{ft}$.

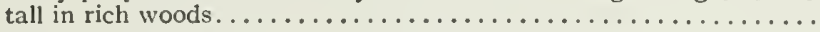

polyganum (Tall Meadowrue). This has lovely white flower heads in Midsummer, and likes either sunny or shady bogs. 1t grows $4 \mathrm{ft}$.

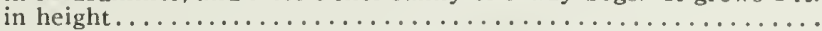

THERMOPSIS caroliniana (Carolina thermopsis). A leguminous plant attaining a height of $4 \mathrm{ft}$., with cloverlike leaves and handsome spikes of golden yellow, pea-shaped flowers in Midsummer. For

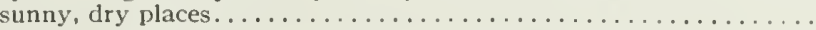

TIARELLA cordifolia (Foamflower). The flowers are fluffy heads of white on 6 to 8 in. stems in May. It is a fine plant for rock gardens. The leaves are evergreen........

$\begin{array}{llll}60 & 1.50 & 12.00 & 100.00\end{array}$

$\begin{array}{llll}60 & 1.75 & 12.00 & 100.00\end{array}$

$\begin{array}{llll}.60 & 1.75 & 12.00 & 100.00\end{array}$

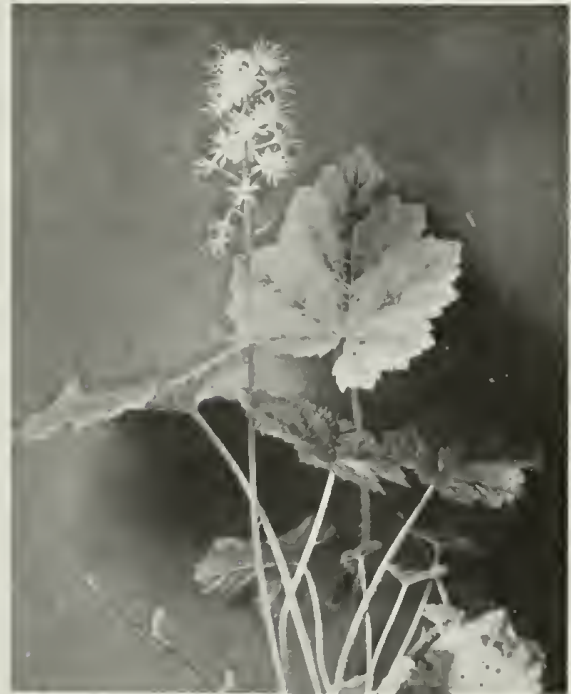

Tiarella cordifolia (Foamflower)

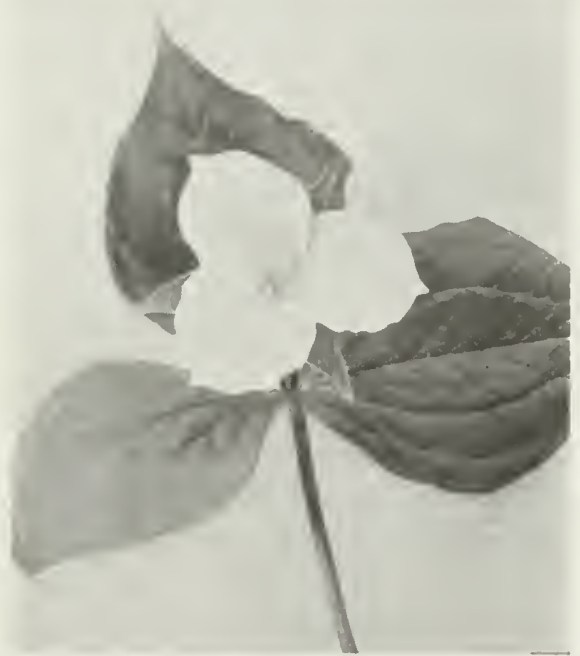

Trillium grandiflorum (Snow Trillium) (See page $\overrightarrow{18}$ )

This price list is for Fall, 1932 only and does not apply to orders for Spring, 1933 


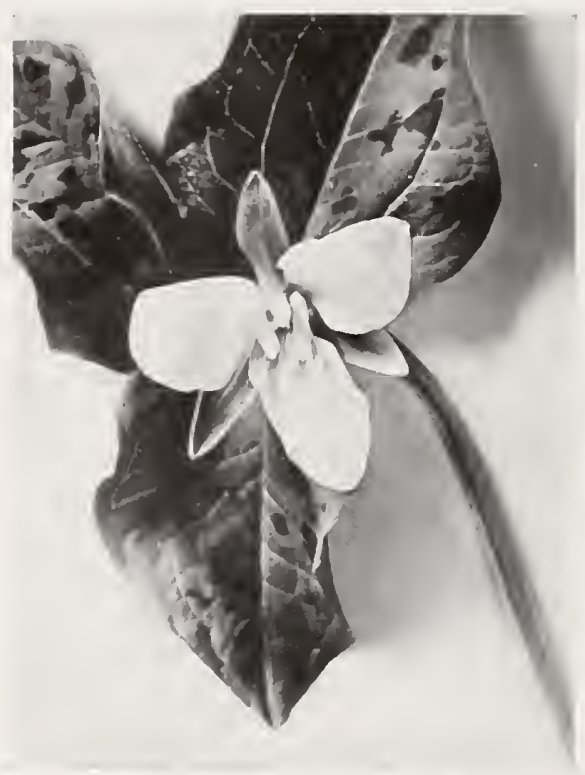

Trillium sessile californicum

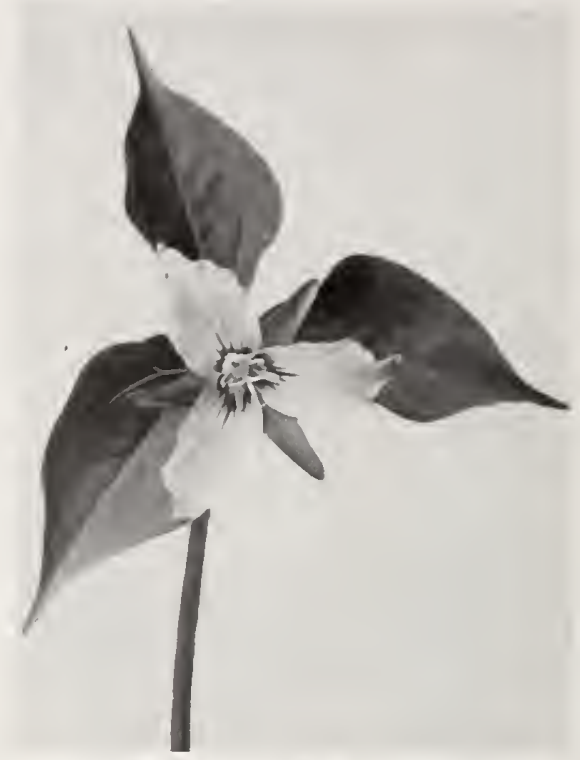

Trillium undulatum (Painted Trillium)

$\begin{array}{lllll}\text { Prices per } & 3 & 12 & 100 \quad 1000\end{array}$

TRADESCANTIA virginica (Spiderwort). The deep blue blossoms of the Spiderwort are borne in open sunny places. . . . . . . . . . . . \$0.60 $\$ 1.75 \$ 12.00 \$ 100.00$

virginica rosea (Pink Spiderwort). A splendid rose pink variety of the common Spiderwort. Easily grown...................

pilosa (Zigzag Spiderwort). 12-18 in. tall and at home on the banks

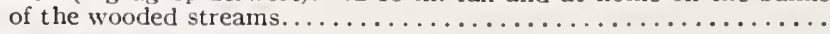

$.60 \quad 2.00 \quad 15.00$

$.60 \quad 1.75 \quad 12.00$

TRIENTALIS americana (Starflower). As the name suggests, the dainty flowers of this plant are star shaped of purest white. It blossoms in June in our native open woods....................

TRILLIUM cernuum (Nodding Trillium). A nodding Trillium, not too common, with blossoms of white. From the moist woods of the

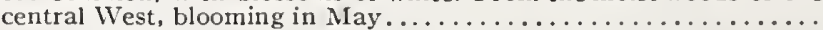

erectum (Wakerobin). Our own native Trillium of deep red, at home in the rich woods, blossoming in May and about a foot tall.......

grandiflorum (Snow Trillium). A most popular Trillium bearing immense white flowers in May, easily grown and should be planted

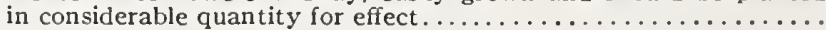

nivale (Dwarf White Trillium). A dwarf White Trillium. This 6 in. variety comes from the central west and is almost the earliest wild flower to blossom. It blooms with the Hepaticas and early yellow Violets and should be a wonderfully good rock garden plant......

recurvatum (Prairie Trillium). The reddish brown recurved sepals make this distinctly different from the other Trilliums. It considers itself better than the others. It is easily grown in shade.........

rivale. A rare little Trillium with mauve flowers from the Pacific states. The plants are but 6 in. tall. With Trillium nivale this Trillium should prove a good variety for rock gardens..........

sessile californicum. The giant white Trillium from northern California seems to be perfectly hardy with us here in Vermont. The flowers are fully as large as Trillium grandiflorum but are stemless.

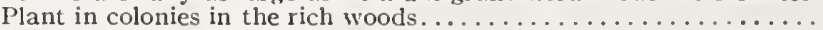

stylosum (Rose Trillium). A partially nodding rose pink Trillium from the southern mountains. Perfectly hardy in the North and

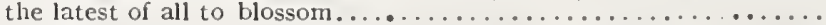

undulatum (Painted Trillium). A white Trillium with pink stripes, colored like peppermint candy sticks, $1 \mathrm{ft}$. tall, blooming in

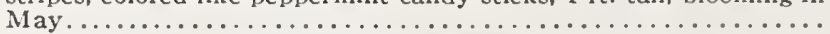

$\begin{array}{lll}60 & 1.75 & 12.00\end{array}$

80.00

$\begin{array}{lll}.75 & 2.50 \quad 18.00\end{array}$

$.60 \quad 1.50 \quad 10.00$

90.00

$\begin{array}{lll}.50 & 1.50 & 8.00\end{array}$

60.00 


\section{Prices per}

312

100

1000

TUSSILAGO farfara (Coltsfoot). The masses of large leaves that appear along the clay banks and brooksides in late Summer are seldom associated with the Dandelionlike flowers which come up all alone in early Spring. Nevertheless they are the leaves of the Coltsfoot .................................... $\$ 0.50 \$ 1.50 \$ 10.00$

TYPHA latifolia (Cattail). To give height and picturesqueness to the

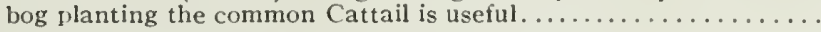

$.50 \quad 1.50 \quad 8.00$

60.00

UVULARIA perfoliata (Merrybells). The blossoms of the plant are like eream yellow Lilies in May. It grows $1 \mathrm{ft}$. tall in the ricl woods and by roadsides

$2.00 \quad 12.00$

100.00

VERATRUM viride (Wild Hellebore). We have not yet ealled any flower a "harbinger of Spring." This sentence seems to have been used before, but in the case of the Wild Hellebore, it is quite true, for the large, bright green leaves arise from the bogs almost before anything else has started. .

VERBENA hastata (Blue Vervain). Slender spikes of royal purple rise 2 to $3 \mathrm{ft}$. tall in August from the roadsides and wet meadows......

$\begin{array}{lll}.60 & 1.50 \quad 10.00\end{array}$

90.00

VERNONIA altissima (Ironwood). Tall growing plant for moist, low ground. 4-6 ft. and with deep purple flowers, arranged in loose

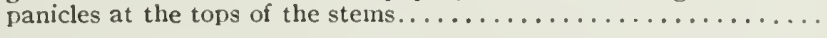

VERONICA officinalis (Common Speedwell). An ordinary little plant with creeping bright blue flowers but is useful for growing under Pine trees or almost any loeation either in sun or shade.........

virginica (Culvers-root). This white flowering Veronica grows $2-4 \mathrm{ft}$. tall in moist woods or meadows and blossoms in late Summer......

VINCA minor (Common Periwinkle). The Vinca minor or Blue Myrtle, while an immigrant, has become thoroughly naturalized. The best, low, evergreen ground cover in our opinion. Heavy field grown plants

VIOLA blanda (Sweet White Violet). This is the tiny sweet white Violet of earliest Spring, which later in Summer develops leaves of such size that they are seldom associated with the tiny flowers of the

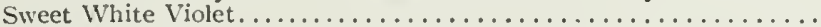

canadensis (Canada Violet). A true northern Violet growing a foot tall, in rich woods. The blossoms are white with a purplish tinge. .

conspersa (Ameriean Dog Violet). A leafy-stemmed blue Violet 6 to

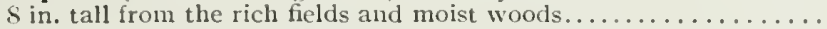

hastata (Halberdleaved Yellow Violet). A yellow Violet common in the southern Appalaelians with leaves shaped like arrowheads.

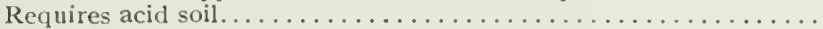

palmata (Palin Violet). A large flowering blue Violet of the dry woods. The blossoms sometimes measure $1 \mathrm{in}$. across...........

pedata (Birdsfoot Violet). This Violet has very large blue flowers and deeply cut leaves growing in a great many gardens but ought to be

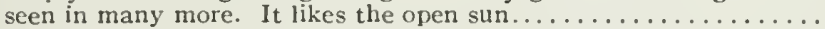

pedata bicolor. A most attractive native Violet the upper part of the large blossoms being blue and the under part the most royal purple imaginable. We cannot recommend it too highly.............

papilionacea (Common Blue Violet). The Common Blue Violet of the open field, blossoming freely in the early Spring ...........

rotundifolia (Early Yellow Violet). A tiny, bright yellow flowered Violet which is about the earliest to bloom, coming soon after the snow leaves. It grows in moist sun or shade..............

pubescens (Downy Yellow Violet). The very tall northern variety with downy leaves. It blossoms in the rich woods in May........

WALDSTEINIA fragraoides (Barren Strawberry). It is too bad we haven't a better common name for the attractive wild flower. It is not common. The glossy green leaves and profusion of Strawberrylike blossoms appear in May and June. 1t prefers shade but is not particular as long as it gets moisture. $1 \mathrm{t}$ grows about 6 in. tall.

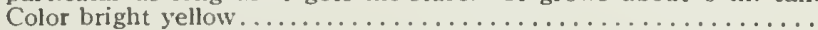

ZIZIA aurea (Early Mleadow Parsnip). This is common enough to us in Vermont but the yellow blossoms in May appeal to all visitors. It grows from 1 to $2 \mathrm{ft}$. tall and thrives by the roadsides...........

\section{$\begin{array}{lll}.60 & 1.75 & 12.00\end{array}$}

$\begin{array}{lll}.50 & 1.50 \quad 10.00\end{array}$

75.00

$\begin{array}{lll}60 & 2.00 & 15.00\end{array}$

$\begin{array}{lll}.60 & 2.00 & 15.00\end{array}$

135.00 $\begin{array}{llll}60 & 2.00 & 15.00 & 120.00\end{array}$

$\begin{array}{lll}.50 & 1.50 & 10.00\end{array}$

80.00

$\begin{array}{llll}.60 & 1.75 & 12.00 & 100.00\end{array}$

$\begin{array}{lll}.60 & 2.00 \quad 15.00\end{array}$

$.60 \quad 2.00 \quad 15.00$

$.60 \quad 2.00 \quad 15.00$

$\begin{array}{lll}60 & 1.75 & 10.00\end{array}$

80.00

$\begin{array}{llll}.60 & 2.00 & 15.00 & 140.00\end{array}$

$\begin{array}{llll}.50 & 1.50 & 8.00 & 60.00\end{array}$

$\begin{array}{llll}.50 & 1.50 & 10.00 & 80.00\end{array}$

$\begin{array}{llll}.60 & 2.00 & 15.00 & 120.00\end{array}$

$\begin{array}{lll}.60 & 1.50 & 10.00\end{array}$

75.00 


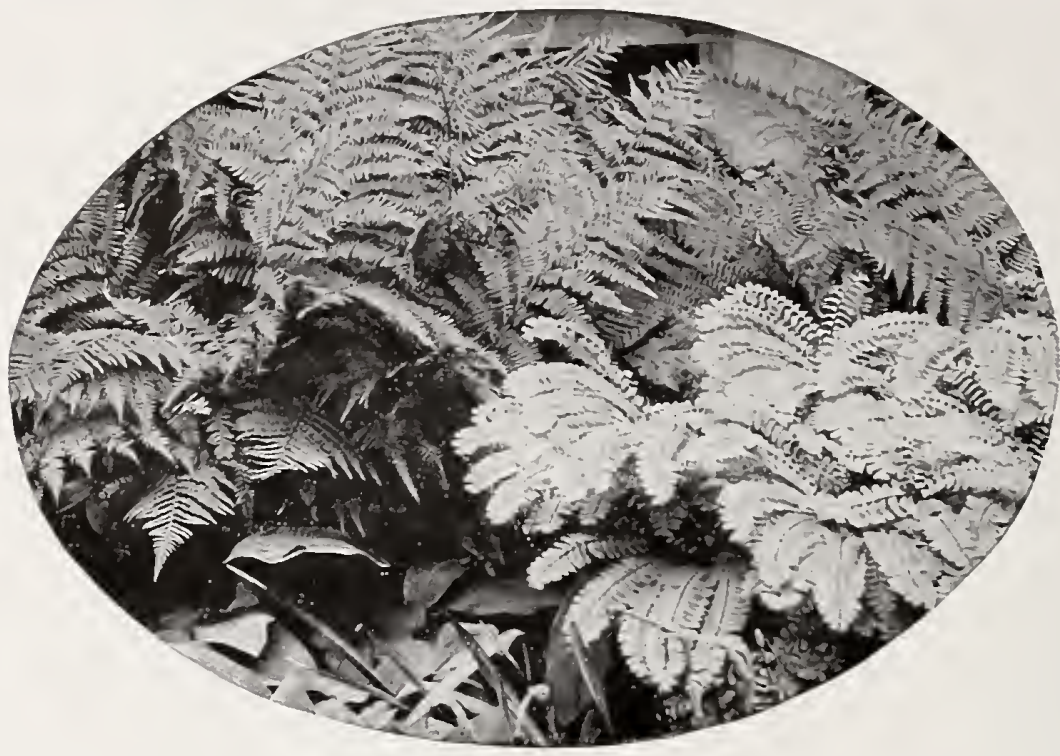

\section{The Hardy Ferns of New England}

Almost the most useful group of all hardy plants are our ferns for there is scarcely a place where the judicious planting of them will not improve it. Their hardiness and useful beauty should endear them to all. Little fellows for the rockery and big fellows for the field and bog. For sun or shade there is a wide range of varieties.

Vermont is the home of the best ferns. Almost every variety native to temperate North America grows here and our plants are much heavier and stronger than those from other sections.

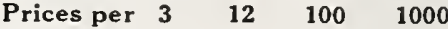

ADIANTUM pedatum (Maidenhair). This most graceful of ferns grows on shady banks among the rocks of the rich woods. It grows $2 \mathrm{ft}$. tall

and is one of the finest.........................\$0.60 $\$ 2.00 \$ 12.00$

ASPLENIUM platyneuron (Ebony Spleenwort). This fern cannot be excelled for a small fern for the shaded rockery. The 6 in. ebony

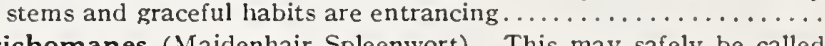

trichomanes (Maidenhair Spleenwort). This may safely be called
the daintiest of all the ferns. It grows from 4 to 6 in. tall and prefers

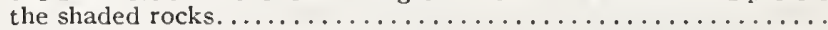

ATHYRIUM felixfemina (Lady Fern). This is a very easily grown, graceful, 2 to $2 \frac{1}{2} \mathrm{ft}$. fern, preferting partial shade but will succeed in

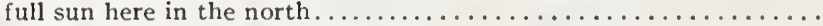

pycnocarpon (Narrowleaf Spleenwort). A large, clean looking fern growing $2 \mathrm{ft}$. or more in height and found in the company of the

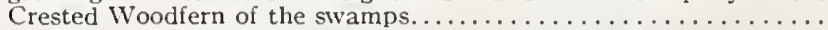

thelpytroides (Silvery Spleenwort). The Silvery Spleenwort resembles the Lady Fern somewhat in size and shape but the spores on the fruit fronds give it a silvery sheen. It likes a partial shade.

BOTRYCHIUM matricariae (The Broadleaf Grapefern). This Grapefern grows about 6 in. tall and with a single leaf. It is often confused with the exceedingly rare Moonwort. It grows in open meadows.

dissectum (Cutleaf Grapefern). This is a finer cutleaf variety than the Rattlesnake Fern.............................

obliquum (Ternate Grapefern). The fruit spores are borne on a stalk separate from the leaf stem. Otherwise it is similar to Rattlesnake

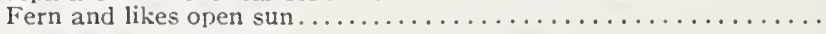

virginianum (Rattlesnake Fern or Grapefern). An attractive fern with unusual fronds for the open woods. It grows 12 to 18 in. tall. .

\section{$\begin{array}{lll}.60 & 1.50 & 10.00\end{array}$}

$\begin{array}{lll}.75 & 2.50 & 18.00\end{array}$

$.90 \quad 2.50 \quad 16.00$

150.00

\section{$.75 \quad 2.50$}

$\begin{array}{lll}60 & 2.00 \quad 14.00\end{array}$

$\begin{array}{lll}1.00 & 3.00 \quad 15.00\end{array}$

160.00

$\begin{array}{llll}60 & 2.00 & 14.00 & 125.00\end{array}$ 
CAMPTOSORUS rhizophyllus (Walking Fern). It has received its name from its peculiar appearance and a novice might not suspect its being a fern. It grows naturally on the rocky cliffs and roots from the tips of the fronds......................... \$0.60\$2.00\$15.00

CYSTOPTERIS bulbifera (Berry Bladderfern). It is nearly always found growing wild on the rocks by the side of small brooks. The

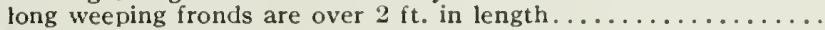

fragilis (Fragile Bladderfern). This is a rather more delicate fern,

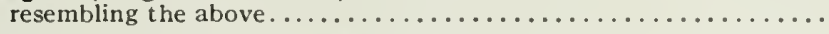

DENNSTEDTIA punctilobula (Hay-scented Fern). A fern which forms dense mats of fragrant fronds $1 \mathrm{ft}$. tall and is one of the best for open sun or woods. When bruised the fronds give off an aroma tike new mown hay. This is a good fern for naturalizing.........

Sods of Hay-scented Fern about 10 in square...............

DRYOPTERIS clintoniana (Clinton Woodfern). A very large type of the crested Woodfern growing to nearly $3 \mathrm{ft}$. and almost evergreen. .

cristata (Crested Woodfern). A rather uncommon Woodfern with dark green fronds from 1 to $2 \mathrm{ft}$. tall and at home in shady swamps.

goldiana (Goldie Fern). This is the targest of all Woodferns with a

chaffy stem and rich dark green fronds from 2 to $4 \mathrm{ft}$. tall........
hexagonoptera (Winged Woodfern). This was formerly called the Broad Beechfern. It resembles the Narrow Beechfern except that the fronds are wider than they are long. It is not very common.

intermedia (Fancy Fern). The fern used extensively by the florists and picked by mittions in the Fatl. It prefers the rich woods and attains a height of $2 \mathrm{ft}$.

linneana (Oakfern). A very tiny attractive 6 in. fern with branched fronds. It likes moist shade........................

marginalis (Evergreen Woodfern). The evergreen fronds are teathery and remain attractive throughout the Winter. This fern likes the

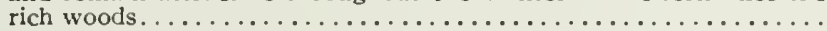

noveboracensis (New York Fern). This small fern is like the Hayscented Fern and grows naturally in the marshy woods and meadows.

phegopteris (Narrow Beechfern). The fronds of the Beechfern are borne at the top of the 6 to 8 in. stems and are shaped like arrow-

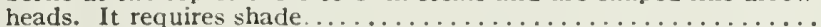

thelypteris (Marshfern). Grows $1 \mathrm{ft}$. tall on open, marshy ground..

LYGODIUM palmatum (Hartford Fern). At last we have a fine supply of this very rare Climbing Fern or Hartford Fern. It grows in acid soil to a height of $2-4 \mathrm{ft}$. climbing up other plants like a true vine. The foliage is most attractive and we are sure that our customers will be glad to get this fern which has been almost extinct.......

ONOCLEA sensibilis (Sensitive Fern). A fern which grows small in the open meadows but attains a height of $3 \mathrm{ft}$. in the wet shade.......

OPHIOGLOSSUM vulgatum (Adderstongue). This is a quaint fern with a single teaf and the stem of the Adderstongue seems sufficient for its single oval leaf and the fruit stalk. It is considered rare but we have it in considerable quantity. It thrives best in the cold open

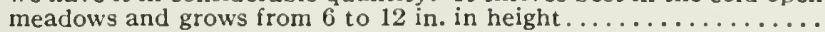

OSMUNDA cinnamomea (Cinnamon Fern). The immense fronds of this fern are $4 \mathrm{ft}$. tall with the fruit stem rising from the center of the plant. This is a fern for partial shade or open meadows..

claytoniana (Interrupted Fern). Possibly this is the largest of our native ferns, attaining a height of $6 \mathrm{ft}$. It is at home in the open

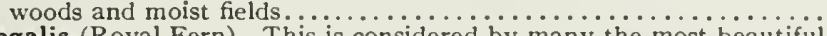

regalis (Royal Fern). This is considered by many the most beautiful of alt ferns. It grows to $3 \mathrm{ft}$. in shady bogs but is smalter in open land. regalis gracilis (Stender Royal Fern). A somewhat slenderer fern than the Royal and apparently at home in drier soil..............

POLYPODIUM vulgare (Common Polypody). This attractive 6 in. evergreen fern forms mats on the shaded rocks...............

$\begin{array}{llll}.60 & 1.50 & 10.00 & 75.00\end{array}$

$\begin{array}{llll}1.00 & 3.00 & 20.00 & 175.00\end{array}$

$\begin{array}{lll}60 & 2.00 \quad 12.00\end{array}$

$\begin{array}{lll}60 & 2.00 \quad 12.00\end{array}$

$1.50 \quad 5.00$

$1.00 \quad 3.00 \quad 20.00$

$\begin{array}{lll}.60 & 2.00 \quad 12.00\end{array}$

90.00

$\begin{array}{llll}.75 & 2.00 & 15.00 & 130.00\end{array}$

$\begin{array}{lll}.60 & 1.75 & 10.00\end{array}$

80.00

$\begin{array}{lll}.60 & 1.50 & 10.00\end{array}$

60.00

$\begin{array}{llll}.60 & 1.50 & 12.00 & 80.00\end{array}$

$\begin{array}{llll}.60 & 1.50 & 10.00 & 75.00\end{array}$

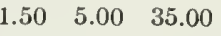

$\begin{array}{lll}60 & 1.50 \quad 10.00\end{array}$

75.00

$\begin{array}{lll}.75 & 2.50 & 18.00\end{array}$

$\begin{array}{llll}.60 & 2.00 & 15.00 & 120.00\end{array}$

$\begin{array}{llll}60 & 2.00 & 15.00 & 120.00\end{array}$

$\begin{array}{llll}.60 & 2.00 & 15.00 & 120.00\end{array}$

$\begin{array}{llll}.60 & 2.00 & 15.00 & 120.00\end{array}$

$\begin{array}{llll}.60 & 1.75 & 12.00 & 80.00\end{array}$

POLYSTICHUM acrostichoides (Christmas Fern). A 12 to 18 in. evergreen fern called Dagger Fern by florists. Fine for shaded rock

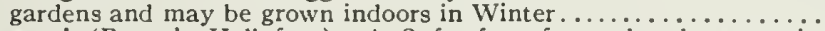

brauni (Braun's Hollyfern). A $2 \mathrm{ft}$. fern from the dense, moist woods. It is conspicuous for its very chaffy stems and considered extremely rare, but plentiful in many Northern locations... . . . . . . .
90.00 $\begin{array}{lll}60 & 2.00 \quad 12.00\end{array}$ 
PTERIDIUM aquilinum (Bracken). The Eagle fern of the open, sunny

$$
\begin{array}{lllll}
\text { Prices per } & 3 & 12 & 100 & 1000
\end{array}
$$

hillsides, growing to a height of $2 \mathrm{ft} \ldots \ldots \ldots \ldots \ldots \ldots \ldots \ldots \ldots \ldots \ldots . \$ 0.50 \$ 1.50 \$ 10.00 \$ 60.00$

PTERITIS nodulosa (Ostrich Fern). This fern has graceful plumes, and grows in moist hollows and along the sunny brooks and ponds. It has plumes 4 to $6 \mathrm{ft}$. tall . . . . . . . . . . . . . . . . .

WOODSIA ilvensis (Rusty Woodsia). This grow from 6 to 8 in. tall and has a brown appearance due to myriads of small brown hairs.

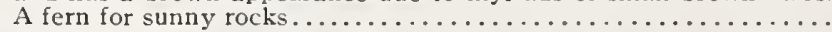

obtusa (Blunt-lobed Woodsia). This most charming variety of the

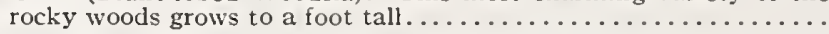

$\begin{array}{llll}.60 & 2.00 & 15.00 & 120.00\end{array}$

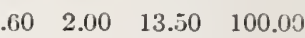

WOODWARDIA areolata (Chainfern). A fern which is native to the wet lands along the Atlantic coast. The fruit spores resemble chain links from which appearance this fern gets its common name..... virginica (Virginia Chainfern). This resembles the areolata, but is

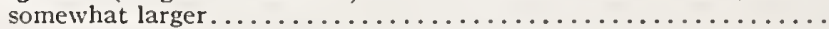

$\begin{array}{llll}.60 & 2.00 & 15.00 & 120.00 \\ .60 & 2.00 & 15.00 & 120.00\end{array}$

\section{Collection $A$}

\section{FERNS FOR WOODLANDS}

12 Maidenhair

12 Lady Fern........

12 Hay-scented Fern.

12 Evergreen Woodfern

12 Cinnamon Fern.

12 Christmas Fern.

12 Royal Fern......

84 Ferns-worth..

This Collection for $\$ 10.00$,

or half the number for $\$ 5.50$

\section{Collection $C$}

\section{PLANTS FOR THE SUNNY HILLSIDE}

12 Butterflyweed......

$\$ 2.00$

12 White Wild-indigo

2.00

12 Shootingstar.

12 Helenium.

12 Flowering Spurge

1.50

2.00

12 Spike Gayfeather.

1.50

12 Spiderwort....

2.00

1.75

st Plants-worth.

$\$ 12.75$

The above 84 plants for $\$ 10.00$, or one-half the Collection for $\$ 5.50$
Collection B

\section{PLANTS FOR THE WOOD. LAND PATHWAY}

\begin{tabular}{|c|c|c|}
\hline 12 & White Baneberry & $\$ 2.00$ \\
\hline 12 & Jack-in-the-pulpit. & 1.50 \\
\hline 50 & Clintonia or Bluebeads. & .5 .00 \\
\hline 50 & Dutchmans-breeches. & 5.00 \\
\hline 50 & Snow Thoroughwort. & 6.00 \\
\hline 50 & Sharplobe Hepatica & 6.00 \\
\hline 100 & Mertensia... & 10.00 \\
\hline 12 & Blue Phlox. & 1.75 \\
\hline 12 & Solomonseal. & 2.00 \\
\hline 50 & Bloodroot. & 5.00 \\
\hline 100 & Snow Trillium. & 3.00 \\
\hline 50 & Canada Violet. & .6 .00 \\
\hline 50 & Troutlily... & 5.00 \\
\hline
\end{tabular}

This Collection for only $\$ 50.00$, or one-half the number for $\$ 27.50$

\section{Collection $D$}

\section{PLANTS FOR THE ROCKERY}

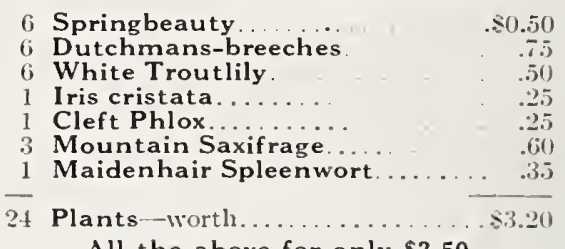

All the above for only $\$ 2.50$

\section{RHODODENDRONS AND AZALEAS}

We have practically all varieties of native Azaleas and Rhododendrons, as well as native shrubs, vines, and evergreens, but as these are listed in our regular catalog, we are onitting them from our wild Hower catalog this year. 


\section{NATIVE PLANTS ESPECIALLY ADAPTED TO ROCK GARDENS}

* Actaea alba

* Actaea rubra

*Aquilegia canadensis

*Aquilegia caerulea

*Aquilegia chrysantha

* Campanula rotundifolia

*Claytonia virginica

Corydalis glauca

Dianthus deltoides

* Dicentra canadensis

* Dicentra cucullaria

* Geranium maculatum

* Geranium robertianum

* Hepatica acutiloba

* Hepatica triloba

Iris cristata

* Iris verna

Lewisia rediviva

Linaria vulgaris

* Mitella diphylla

Varieties marked * are suited to shady rocks. Unmarked for sun.

*Oakesia sessilifolia

Oenothera speciosa

* Phlox divaricata

Phlox pilosa

* Phlox reptans

Phlox subulata

Polemonium reptans

*Polygonatum biflorum

Potentilla tridentat

*Pyrola elliptica

Ranunculus bulbosa

Salvia azurea

* Sanguinaria canadensis

Saxifraga virginiensis

Silene pennsylvanica

Silene virginica

* Tiarella cordifolia

*Trientalis american

*Trilliums

*Uvularia perfoliata
Veronica officinalis

*Viola canadensis

Viola pedata

Viola pedata bicolor

*Viola pubescens

* Oakfern

* Beechfern

*Common Polypody

Christmas Fern

*Woodsias

* Maidenhair Fern

* Ebony Spleenwort

* Maidenhair Spleenwort

*Walking Leaf

Hay-scented Fern

* Fancy Fern

*Winged Woodfern

*Bladderfern

\section{WILD FLOWERS ADAPTED TO BROOKSIDE PLANTING}

Caltha palustris

Lobelia cardinalis

Lobelia siphylitica

Lythrum salicaria roseum

Mentha peperita

Mentha spicata

Monarda didyma

Myosot is scorpiodes

Physostegia speciosa

Ranunculus repens

Sagittaria latifolia

Sanguisorba ca nadensis

Thalictrum polygamum

Tussilago farfara

Verbena hastata

Zizia aurea

Osmunda Ferns

Ostrich Fern

Lady Fern

\section{PLANTS ADAPTED TO BOG GARDENS}

Acorus calamus

Asclepias incarnata

Aster puniceus

* Calla palustris

*Caltha palustris

* Chelone glabra

Cicuta maculata

*Coptis trifolia

Drosera rotundifolia

Eupatorium perfoliatum

Eupatorium purpureum

Geum rivale

Habenaria ciliaris

Habenaria blephariglot t is

* Habenaria fimbriata

Those marked $*$ will thrive in shade. Unmarked varieties are for sun.

* Habenaria psycodes
lris prismatica
lris pseudacorus
lris versicolor
Lysimachia quadrifolia
Lythrum salicaria roseum
Mimulus ringens
Parnassia caroliniana
Physostegia virginica
Pogonia ophiglossoides
Sagittaria latifolia
Sarrecenia flava
Sarrecenia purpurea
Saxifraga pennsylvanicum

Scirpus atrovirens

Senecio aureus

* Spathyema foetida

Spiranthes cernua

Thalictrum polygamum

Typha latifolia

* Veratrum viride

Viola blanda

Viola rotundifolia

* Dryopteris cristata

Dryopteris noveboracensis

Dryopteris thelypteris

* Onoclea sensibilis

Ophioglossum vulgatum

*Osmunda regalis

\section{PLANTS ADAPTED TO MOIST SHADE}

Aconitum uncinat um

Anemone quinquefolia

Anemonella thalictroides

Arisaema triphyllum

Aralia nudicaulis

Aster cordifolius

Aster umbellatus

Caulophyllum thalictroides

Claytonia virginica

Clintonia borealis

Cimicifugas

Cornus canadensis

Cypripediums

Dentaria diphyllum

Dicentra eximia

Equisetum hyemale

Erythroniums

Eupatorium urticaefolium

Habenaria hookeri
Hydrophyllum virginianum

Linnaea americana

Orchis spectabilis

Oxalis violacea

Streptopus roseus

Thalictrum diocium

Tiarella cordifolia

Trilliums

Waldsteinia fragarioides

Nearly all Ferns
Anemone cylindrica

Aralia hispida

Asclepias tuberosa

Baptisia bracteata

Baptisia leucantha

Baptisia tinctoria

Callirhoe involucrata

Chrysanthemum leucanthemum

Dianthus doltoides

\section{Aquilegias}

Asarum canadense

Chimaphila umbellata

Dicentra canadensis

Dodecatheon meadia

Epigaea repens

Gaultheria procumbens

Gerardia virginica

Goodyera pubescens

\section{PLANTS FOR DRY SUNNY SLOPES}

Dodecatheon meadia

Echinacea purpurea

Epilobium angustifolium

Helenium autumnale

Inula helenium

Lewisias

Liatris

Linaria vulgaris

Lobelia spicata

Oenothera speciosa
Pentstemons

Phlox pilosa

Phlox subulata

Phytolacca americana

Rudbeckia hirta

Silene stellata

Stylophyllum diphyllum

Tradescantia virginica

Viola papilionacea

Pteritis aquilinum

\section{PLANTS FOR DRY SHADE}

\section{Helianthus}

lris verna

Lilium philadelphicum

Medeola virginica

Mertensia virginica

Moneses uniflora

Pedicularis canadensis

Phlox divaricata

Phlox reptans

Polemonium reptans
Polygala paucifolia

Polygonatum biflorum

Pyrolla elliptica

Sanguinaria canadensis

Trientalis americana

Botrychium obliquum

Botrychium virginanum

Dennstedtia punctilobula
Dryopteris phegopteris 


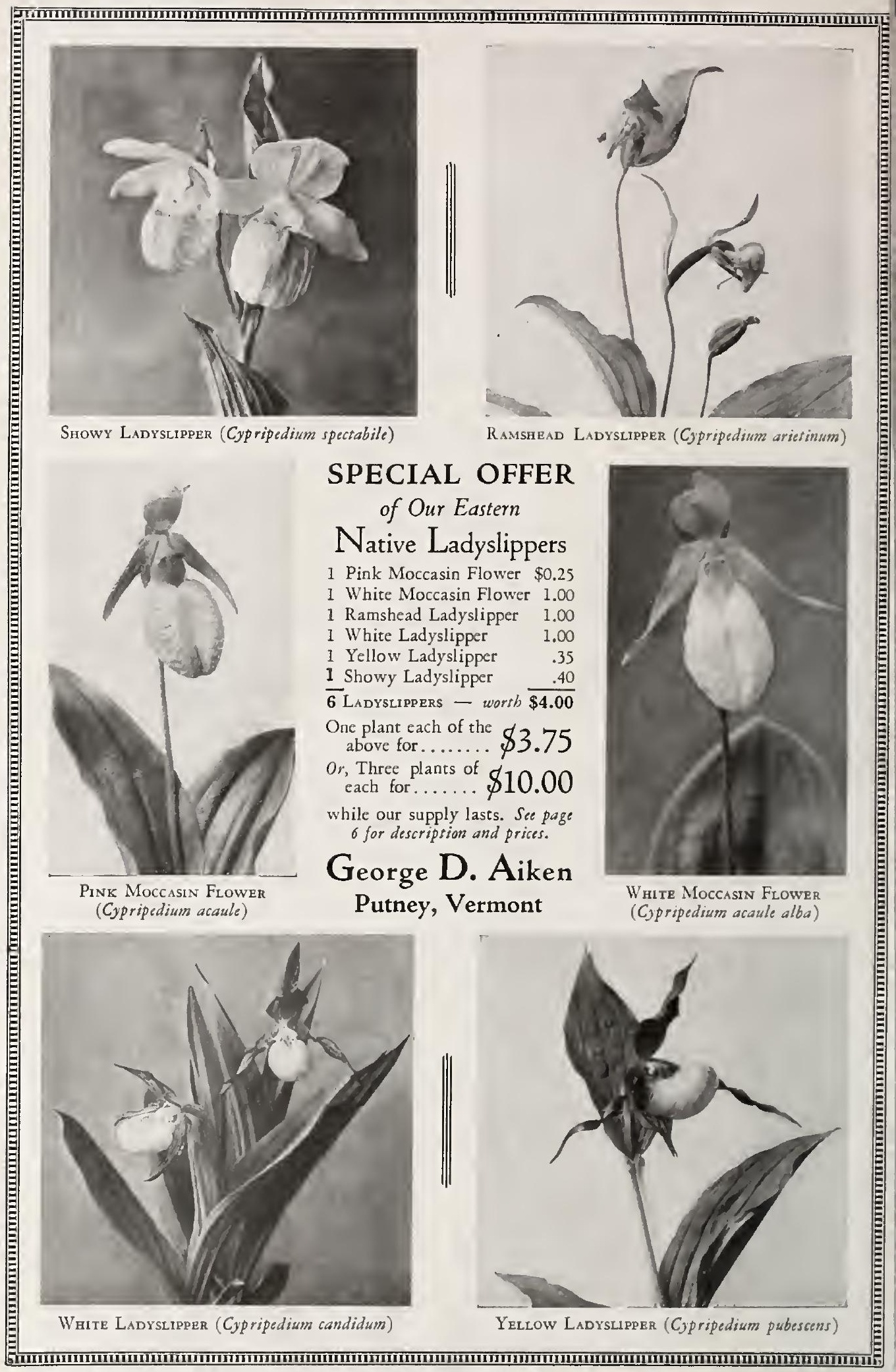

